\title{
BACE1, a Major Determinant of Selective Vulnerability of the Brain to Amyloid- $\beta$ Amyloidogenesis, is Essential for Cognitive, Emotional, and Synaptic Functions
}

\author{
Fiona M. Laird, ${ }^{1 *}$ Huaibin Cai, ${ }^{5 *}$ Alena V. Savonenko, ${ }^{1,2 *}$ Mohamed H. Farah, ${ }^{1 *}$ Kaiwen He, ${ }^{6}$ Tatyana Melnikova, ${ }^{1,2}$ \\ Hongjin Wen, ${ }^{1}$ Hsueh-Cheng Chiang, ${ }^{1}$ Guilian Xu, ${ }^{1}$ Vassilis E. Koliatsos, ${ }^{1,2,3,4}$ David R. Borchelt, ${ }^{1,3}$ Donald L. Price,,${ }^{1,2,3}$ \\ Hey-Kyoung Lee, ${ }^{6}$ and Philip C. Wong ${ }^{1,3}$ \\ Departments of ${ }^{1}$ Pathology, ${ }^{2}$ Neurology, ${ }^{3}$ Neuroscience, and ${ }^{4}$ Psychiatry and Behavioral Sciences, The Johns Hopkins University School of Medicine, \\ Baltimore, Maryland 21205, ${ }^{5}$ Laboratory of Neurogenetics, National Institutes of Health, Bethesda, Maryland 20892, and ${ }^{6}$ Department of Biology, \\ University of Maryland, College Park, Maryland 20742
}

A transmembrane aspartyl protease termed $\beta$-site APP cleavage enzyme 1 (BACE1) that cleaves the amyloid- $\beta$ precursor protein (APP), which is abundant in neurons, is required for the generation of amyloid- $\beta(\mathrm{A} \beta)$ peptides implicated in the pathogenesis of Alzheimer's disease (AD). We now demonstrate that BACE1, enriched in neurons of the CNS, is a major determinant that predisposes the brain to $\mathrm{A} \beta$ amyloidogenesis. The physiologically high levels of BACE1 activity coupled with low levels of BACE2 and $\alpha$-secretase anti-amyloidogenic activities in neurons is a major contributor to the accumulation of $\mathrm{A} \beta$ in the CNS, whereas other organs are spared. Significantly, deletion of $B A C E 1$ in APPswe;PS1 $\triangle E 9$ mice prevents both $\mathrm{A} \beta$ deposition and age-associated cognitive abnormalities that occur in this model of $\mathrm{A} \beta$ amyloidosis. Moreover, $\mathrm{A} \beta$ deposits are sensitive to BACE1 dosage and can be efficiently cleared from the CNS when BACE1 is silenced. However, BACE1 null mice manifest alterations in hippocampal synaptic plasticity as well as in performance on tests of cognition and emotion. Importantly, memory deficits but not emotional alterations in $B A C E 1^{-1-}$ mice are prevented by coexpressing APPswe;PS1 $\triangle E 9$ transgenes, indicating that other potential substrates of BACE1 may affect neural circuits related to emotion. Our results establish BACE1 and APP processing pathways as critical for cognitive, emotional, and synaptic functions, and future studies should be alert to potential mechanism-based side effects that may occur with BACE1 inhibitors designed to ameliorate A $\beta$ amyloidosis in AD.

Key words: BACE1 null mice; selective vulnerability; $\mathrm{A} \beta$ amyloidosis; Alzheimer's; cognition; synaptic plasticity; RNAi

\section{Introduction}

Alzheimer's disease (AD), the most common cause of dementia in the elderly (Morris and Price, 2001; Mayeux, 2003; Petersen, 2003), selectively damages the brain but does not involve other tissues/organs. Although the biological basis for the selective vulnerability of the brain to amyloid- $\beta(\mathrm{A} \beta)$ amyloidosis is not well understood, we postulate that high levels of amyloid- $\beta$ precursor protein (APP) and levels and activities of $\beta$-site APP cleavage enzyme 1 (BACE1), a proamyloidogenic enzyme, play critical

Received April 4, 2005; revised 0ct. 10, 2005; accepted Nov. 3, 2005.

This work was supported by National Institute of Neurological Disorders and Stroke Grants R01 NS41438, R01 NS45150, and P01 NS047308 (P.C.W.), National Institute on Aging Grant P50 AG05146 (D.L.P.), the Rotary CART Fund (P.C.W.), the American Health Assistance Foundation (P.C.W.), the Adler Foundation (H.C.), and the BristolMyers Squibb Foundation (D.L.P.). M.H.F. is supported by National Research Service Award AG02556 and the John Douglas French Foundation. We are grateful to G. Cristostomo, A. Kecojevic, and V. Nehus for technical support, G. Rudow and J. Troncoso for advice on stereology methods, and J. Hardy for critical reading of this manuscript.

*F.M.L., H.C., A.V.S., and M.H.F. contributed equally to this work.

Correspondence should be addressed to Philip C. Wong, Department of Pathology, The Johns Hopkins University School of Medicine, 558 Ross Research Building, 720 Rutland Avenue, Baltimore, MD 21205-2196. E-mail: wong@jhmi.edu.

G. Xu's and D. R. Borchelt's present address: Department of Neuroscience, University of Florida, Gainesville, FL 32610.

DOI:10.1523/JNEUROSCI.2766-05.2005

Copyright $\odot 2005$ Society for Neuroscience $\quad$ 0270-6474/05/2511693-17\$15.00/0 roles in the susceptibility of the CNS to this disease (Holsinger et al., 2002; Yang et al., 2003). In the CNS, A $\beta$ peptides are generated by sequential endoproteolytic cleavages of neuronal APP by two membrane-bound enzyme activities: BACE1 cleaves APP to generate APP- $\beta$ C-terminal fragments (APP- $\beta$ CTFs) (Hussain et al., 1999; Sinha et al., 1999; Vassar et al., 1999; Yan et al., 1999; Lin et al., 2000), and the $\gamma$-secretase cleavage of APP- $\beta$ CTFs leads to secretion of $A \beta$ peptides (Francis et al., 2002; De Strooper, 2003; Selkoe and Kopan, 2003; Takasugi et al., 2003). APP can also be cleaved within the $\mathrm{A} \beta$ sequence through an alternative, nonamyloidogenic pathway involving $\alpha$-secretase, thought to be tumor necrosis factor- $\alpha$ converting enzyme (TACE) (Allinson et al., 2003), or BACE2 (Farzan et al., 2000; Yan et al., 2001). Despite initial efforts to clarify the physiological roles of APP and its derivatives (Zheng et al., 1995; Dawson et al., 1999), their exact functions remain elusive. Emerging evidence indicates that $\gamma$-secretase cleavages of the APP- $\beta$ CTF or $\alpha$ CTF leads to the release of cytosolic fragments termed the APP intracellular domain (AICD), which forms a multimeric complex with Fe65, a nuclear adaptor protein (Cao and Sudhof, 2001). This complex or Fe65 alone enters the nucleus and binds to the histone acetyltransferase Tip60 to regulate gene transcription (Cao and Sudhof, 2001; Baek et al., 2002; Cao and Sudhof, 2004). An APP and 
Fe65 complex has also been implicated in neurite growth and synapse modification (Sabo et al., 2003). Because BACE1 cleavage of APP is critical in $\mathrm{A} \beta$ amyloidosis, it has been suggested that inhibition of BACE1 would be an attractive strategy to ameliorate $\mathrm{A} \beta$ deposition in AD (Citron, 2002; Vassar, 2002). Supporting this notion are studies demonstrating that deletion of BACE1 prevents $A \beta$ secretion in cultured neurons and in brain (Cai et al., 2001; Luo et al., 2001; Roberds et al., 2001; Wong et al., 2002; Luo et al., 2003), and that young (before $\mathrm{A} \beta$ deposits) mutant $A P P$ mice lacking $B A C E 1$ do not develop memory deficits (Ohno et al., 2004). However, it is unclear whether deletion of BACE1 will prevent age-associated memory impairments in aged mutant $A P P$ mice. Moreover, it is not known whether $\mathrm{A} \beta$ deposition or $\mathrm{A} \beta$-associated cognitive deficits in these mice are sensitive to the dosage of BACE1. It will be important to assess the consequences of partial deletion of BACE1 because complete inhibition of this enzyme could potentially be associated with problems for several reasons. First, additional BACE1 substrates may exist (Kitazume et al., 2001; Gruninger-Leitch et al., 2002; Lichtenthaler et al., 2003; Li and Sudhof, 2004; Wong et al., 2005), and the consequences of inhibiting these processing events are unknown. Second, $\mathrm{A} \beta$ may normally play an important role in modulating activities of certain synapses (Kamenetz et al., 2003). Consequently, chronic inhibition of BACE1 could be associated with mechanism-based toxicities. Although it is not clear whether deletion of BACE1 impacts on cognition in older individuals, the recent findings that 4 -month-old $B A C E 1$ knock-out mice have mild deficits in a task that assesses spatial memory (Ohno et al., 2004) suggests that chronic reduction in BACE1 activity could impact learning and memory.

Thus, despite recent advances, several key issues remain to be addressed. Here, we assessed whether the relative levels of BACE1 and BACE2 activities in neurons predispose the brain to amyloidosis. In addition, we determined whether age-associated memory deficits occurring at advanced age in mouse models of $\mathrm{A} \beta$ amyloidosis can be prevented in the absence of BACE1 and whether $\mathrm{A} \beta$ deposition is sensitive to the dosage of $B A C E 1$ and efficiently cleared from the brain by silencing $B A C E 1$. Furthermore, we evaluated the involvement of BACE1 and the APP processing pathway in cognitive, emotional, and synaptic functions. Results of these studies indicate that the balance of various BACE1dependent processes appear to be important for both normal and abnormal behavioral performance. These discoveries are critical for the design and testing of novel therapeutic strategies for AD.

\section{Materials and Methods}

\section{Immunoblot analysis and ELISA}

Mouse tissues were dissected and homogenized in T-PER buffer (Pierce, Rockford, IL) in the presence of protease inhibitors (Roche Products, Welwyn Garden City, UK). After homogenization, the lysates were centrifuged at $100,000 \times g$, and the supernatants were saved for Western blot, Ciphergen (Palo Alto, CA) ProteinChip Array, and A $\beta$ ELISA analyses. Equal amounts of lysates were subject to SDS-PAGE (Tris-glycine mini gel; Invitrogen, Carlsbad, CA) and Western blot analysis using antibodies specific for the following: BACE1 [1:2500 (Cai et al., 2001)]; BACE2 (1:1000; AnaSpec, San Jose, CA); APP (1:1000; Chemicon, Temecula, CA); presenilin-1 (PS1) (1:2000; Chemicon); GFAP (1:5000; Sigma, St. Louis, MO); $\beta 3$-tublin (1:5000; Covance Research Products, Berkeley, CA); and actin (1:5000; Chemicon). The quantitative sandwich ELISA was used to determine levels of both $\mathrm{A} \beta_{1-42}$ and $\mathrm{A} \beta_{1-40}$ in the conditional media of primary cultured cortical neurons and astrocytes and in brain lysates of mutant transgenic mice as suggested by the manufacturer (Biosource International, Camarillo, CA).

\section{Primary cultures, infection, and metabolic labeling}

Cortical neuronal cultures were established from brains of embryonic day 16.5 fetal mice following published protocols (Naruse et al., 1998). After $7 \mathrm{~d}$ of culture, the cells were infected with $5 \times 10^{6}$ plaque-forming units of adenovirus expressing APPswe for $4 \mathrm{~d}$ in serum-free medium. For metabolic labeling, neuronal cells were preincubated for $30 \mathrm{~min}$ in methionine-free DMEM with $1 \%$ dialyzed bovine serum and then labeled with $500 \mu \mathrm{Ci} / \mathrm{ml}^{35} \mathrm{~S}$-methionine in methionine-free medium for $5 \mathrm{~h}$. After metabolic labeling, cell extracts were immunoprecipitated with an APP C-terminal antibody (Chemicon), and the immunoprecipitates were fractionated on $4-20 \%$ Tris-glycine SDS-PAGE. The gels were dried and exposed, and radioactive bands were quantified by phosphorimaging analyses. For cortical astrocyte cultures, the dissected brain cortices were suspended in HBSS supplemented with $0.25 \%$ trypsin and $0.01 \%$ DNaseI and incubated at $37^{\circ} \mathrm{C}$ for $10 \mathrm{~min}$. The tissues were then transferred to DMEM supplemented with $10 \%$ fetal bovine serum and dissociated by repeated trituration. The dispersed cells were collected by centrifugation and plated at $\sim 1 \times 10^{6}$ cells per well on six-well cell culture plates (coated with poly-D-lysine) in DMEM supplemented with $10 \%$ fetal bovine serum. Astrocytes were allowed to mature for $3 \mathrm{~d}$ in culture before they were treated with $10 \mathrm{~mm}$ glutamate to kill the neurons and split once in DMEM supplemented with $10 \%$ fetal bovine serum on an uncoated culture dish, before they were infected with $5 \times 10^{6}$ plaqueforming units of adenovirus expressing human APPswe or BACE1 for $4 \mathrm{~d}$. The conditional medium and cell lysates were saved for later analysis.

\section{Ciphergen ProteinChip array}

On each spot of PS1 series ProteinChip array, $1 \mu \mathrm{g}$ of purified 6E10 monoclonal antibody (Signet Laboratories, Dedham, MA) was applied and incubated at room temperature for $1 \mathrm{~h}$ in a humidified chamber. After blocking the unbound chip surface with $0.1 \mathrm{M}$ glycine, $\mathrm{pH} 8.0$, for 30 min and washing the chip three times with PBS buffer containing $0.5 \%$ Triton X-100, samples were added onto antibody-coated spots and incubated for $2 \mathrm{~h}$ at room temperature. After extensive wash with PBS buffer in the presence of $0.5 \%$ Triton X-100 followed by 5 mM HEPES buffer, $\mathrm{pH} 7.5$, chips were analyzed by surface-enhanced laser desorption/ionization time of flight mass spectrometry (Ciphergen) in the presence of CHCA matrix solution. Mass identification was made on each spot by 100 averaged shots. External standards were used for calibration.

\section{Animals}

BACE1 knock-out mice, mouse/humanAPPswe (line C3-3), and human $P S 1 \triangle E 9$ (line S-9) transgenic mice were generated as described previously (Borchelt et al., 1996; Lee et al., 1997; Cai et al., 2001). To generate a cohort of 16- to 18-month-old APPswe;PS1 $\triangle E 9$ mice with zero, one, or two alleles of $B A C E 1, B A C E 1^{+/-}$mice (C57BL/6/J;129/Sv background) were first crossed with APPswe (C57BL/6/J background) or PS1 $1 E 9$ (C57BL/6/J background) mice to create APPswe;BACE1 ${ }^{+/-}$and PS1 $\triangle E 9$; $B A C E 1^{+/-}$mice (F1). Subsequently, F1 APPswe;BACE1 $1^{+/-}$and F1 $P S 1 \triangle E ; / B A C E 1^{+/-}$mice were intercrossed to obtain five groups of mice (F2) used for behavioral testing at 16-18 months of age: APPswe; PS1 $1 E 9, \quad$ APPswe;PS1 $1 E 9 ; B A C E 1^{-/-}, \quad$ APPswe;PS1 $1 E 9 ; B A C E 1^{+/-}$, $B A C E 1^{-/-}$, and nontransgenic mice. This F2 cohort of mice therefore possesses the C57BL/6 and 129sv hybrid background. We verified that the effect of the transgene(s) was not influenced by this hybrid genetic background by confirming that the C57BL/6 and 129 sv hybrid background used in our study did not significantly affect our ability to detect genotype-related differences (supplemental Figs. S1, S2, available at www. jneurosci.org as supplemental material).

A second cohort of $B A C E 1^{-/-}, B A C E 1^{+/-}$, and nontransgenic mice of 3-6 months of age was generated from intercrosses of $B A C E 1^{+/-}$mice on $\mathrm{C} 57 \mathrm{BL} / 6 / \mathrm{J}$ congenic background. All procedures involving animals were under the guidelines of Johns Hopkins University Institutional Animal Care and Use Committee.

\section{Histology and immunohistochemical analysis}

Mice were perfused with $4 \%$ paraformaldehyde in PBS. The brain was removed, embedded in paraffin, sectioned, and processed for both histological and immunohistochemical analyses. Hirano silver stain used Hirano's modification of the Bielschowsky method (Yamamoto and 
Hirano, 1986; Borchelt et al., 1996), and Congo red staining was performed according to standard techniques. For immunohistochemical studies, the peroxidase-antiperoxidase method used antibodies specific for the following: BACE1; synaptophysin (Dako, High Wycombe, UK); syntaxin (Sigma); GFAP (Sigma); F4/80 (Serotec, Oxford, UK); and microtubule-associated protein 2 (MAP2) (Sigma). Sections were counterstained with hematoxylin and eosin. For BACE1 immunostaining, an IgG purified anti-BACE1 fusion protein antibody was applied $(1 \mu \mathrm{g} / \mu \mathrm{l})$ as primary antibody in Tris-buffered saline buffer $(10 \mathrm{~mm}$ Tris- $\mathrm{HCl}$ and $150 \mathrm{~mm} \mathrm{NaCl}, \mathrm{pH} 7.5$ ) after retrieving the antigen by heating the sections in the microwave.

\section{Filter trap assay}

For filter trap assay (Xu et al., 2002), we used one hemisphere from the brains of APPswe;PS1 $1 E 9$ and APPswe;PS1 $\triangle E 9 ; B A C E 1^{+/-}$mice at 12 and 20 months of age, whereas the other hemispheres were used for stereological analyses. Cellulose acetate membranes with $0.2 \mu \mathrm{m}$ pore size (OE66; Schleicher \& Schuell, Keene, NH) were used to trap the A $\beta$ aggregates from the brain lysate. Briefly, mouse brains were weighed and then homogenized in $10 \mathrm{vol}$ of PBS, $\mathrm{pH}$ 7.4, containing a protease inhibitor mixture (Roche Products). Homogenates were centrifuged at $3000 \mathrm{rpm}$ for $5 \mathrm{~min}$ at $4^{\circ} \mathrm{C}$ in a microcentrifuge. The protein concentrations in the supernatants were determined by the BCA method (Pierce). Before filtering, the samples were diluted with PBS (100-200 $\mu \mathrm{l}$ ) and adjusted to a final concentration of $1 \%$ SDS. After filtering, using a 96-well dot-blot apparatus (Bio-Rad, Hercules, CA), the membranes were washed twice with $500 \mu \mathrm{l}$ of PBS, pH 7.4, per well. Proteins trapped by the filter were detected by immunostaining following protocols used in immunoblotting.

\section{Unbiased stereology}

A stereological method (Jankowsky et al., 2003) was performed to quantitatively analyze the fraction of the hippocampus occupied by neuritic plaques as immunostained with an anti-ubiquitin antibody (Sigma). The hippocampal region was outlined under a microscope equipped with stepping motors driven by Stereo Investigator Software (MicroBrightField, Colchester, VT). Starting from a random site, a counting frame with a superimposed counting grid composed of small equidistant "crosses" was generated to systematically sample the outlined field. We counted the total number of crosses (intersections) and the crosses that coincided with immunoreactivity "hits." Finally, the fractional area (FA) was calculated as the sum of hits for all counted frames divided by the total number of crosses. According to the Delesse principle, the FA is equal to the fraction of the volume occupied by the neuritic plaques being quantified.

\section{Behavioral testing}

Groups. In the first cohort, five groups of 16- to 18-month-old mice were behaviorally tested: APPswe;PS1 $\triangle E 9$ mice $(n=14)$; APPswe;PS1 $1 E 9$; $B A C E 1^{-/-}$mice $(n=6) ; A P P s w e ; P S 1 \triangle E 9 ; B A C E 1^{+/-}$mice $(n=22)$; $B A C E 1^{-1-}$ mice $(n=11)$; and nontransgenics $(n=15)$. Approximately equal numbers of female and male mice were used (females, $44 \%$; males, $56 \%)$. Female to male ratio for each genotype was as follows: APPswe;

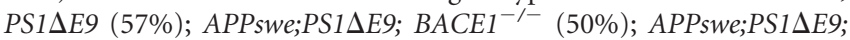
$B A C E 1^{+/-}(41 \%) ; B A C E 1^{-1-}(36 \%)$; and non-transgenic mice $(40 \%)$. All mice were analyzed in three behavioral tasks: first, in the classic Morris water maze task; second, in the visual discrimination task; and finally, in the open field. A second cohort of mice was tested at 3 months of age: nontransgenics $(n=7), B A C E 1^{+/-}$mice $(n=20)$, and $B A C E 1^{-/-}$mice $(n=7)$. In this cohort only, male mice were used and testing was performed in the classic Morris water maze task, radial water maze task, Y-maze, plus maze, and on an open-field task. Before behavioral testing, all mice were intensively handled ( $5 \mathrm{~d}$ by $\sim 3 \mathrm{~min}$ per mouse) and weighed once a week.

Classic Morris water maze task. Testing was conducted as described previously (Savonenko et al., 2005). Before the task, mice were pretrained to climb and stay on a submerged platform $(10 \times 10 \mathrm{~cm})$ placed in the center of a small pool (diameter, $45 \mathrm{~cm}$ ). During the pretraining $(2 \mathrm{~d}$ for five trials), a mouse was placed in the water (face to the platform) and allowed to swim, climb on the platform, and stay there for $10 \mathrm{~s}$. Then it was picked up by tail, dried with a paper towel, and returned to a warm dry waiting cage for 7-8 $\mathrm{min}$ (an average duration of intertrial interval). Thus, before starting the classic Morris water maze task, all mice were familiarized with procedural aspects of the task. The Morris water maze task was conducted in the pool (diameter, $100 \mathrm{~cm}$ ) filled with opaque water $\left(22 \pm 2^{\circ} \mathrm{C}\right)$ and surrounded by a set of distal and proximal spatial cues. Four daily sessions included 10 platform trials, in which the platform was submerged but accessible to the mouse, as well as two probe trials (before and after the block of platform trials). During the probe trials, the platform was collapsed at the bottom of the tank for variable intervals $(30-40 \mathrm{~s})$. At the end of the probe trial, the collapsed platform was returned to its raised position, and the mouse was allowed to escape onto the platform. This probe trial protocol ensured the same responsereinforcement contingency as in the platform trials and allowed the use of probe trials repeatedly without the effect of extinction. If the mouse failed to locate the platform in $60 \mathrm{~s}$, the experimenter directed the mouse to the platform by hand and the mouse remained on the platform for $10 \mathrm{~s}$. Distance (path from the start location to the platform, in centimeters) and swim speed (average speed during a trial, in centimeters per second) were measured during the platform trials. In the probe trials, the measures recorded were swim speed, percentage of time spent in different quadrants, as well as time spent in the area $40 \mathrm{~cm}$ in diameter around the location of platform (annulus 40).

Visual discrimination task in the water maze. After the Morris water maze task, mice were pretrained to swim to and climb on a visible platform as described for pretraining with hidden platform. The platform was made visible by the attachment of a high-contrast extension $(1.5 \mathrm{~cm}$ above water surface). Thus, before starting the visual discrimination task, mice were familiarized with a visible platform as a new escape platform to minimize possible confounding effects of neophobia and strategy of searching for hidden platform. Visual discrimination training was conducted in a $100 \mathrm{~cm}$ pool with spatial cues removed and consisted of two daily sessions of six trials each. For every trial, the visible platform was located in a different quadrant of the pool and at a different distance from the walls. The start position was changed randomly for each trial. Measures of performance were the same as those for the platform trials in the Morris water maze task.

Radial water maze. The radial water maze task was conducted as described by Savonenko et al. (2005). Briefly, clear plastic inserts $(30 \times 50$ $\mathrm{cm}$ ) were placed within the Morris water maze such that six arms were created within the pool. Training took place over $6 \mathrm{~d}$ with daily new position of the platform. Each training session consisted of six trials, in which the mouse was placed at different start positions from trial to trial and allowed $120 \mathrm{~s}$ to find the hidden platform located at the end of one of the maze arms. Two additional sessions were run with the same protocol, except that the start position was constant across the session. Distance to the platform and the number of errors (entry of the mouse into an arm that did not hold the platform) were recorded for each trial.

Spontaneous alternation task in Y-maze. Testing was performed on a Y-shaped maze as described by Andreasson et al. (2001). Mice were place into the end of one arm and allowed to explore freely for $5 \mathrm{~min}$. The sequence of arm entries was recorded. The spontaneous alternation behavior was calculated as the number of triads containing entries into all three arms divided by the maximum possible alternations.

Plus mask task. A plus maze described by Andreasson et al. (2001) was used for testing anxiety in the young cohort of mice. For this test, the maze was raised $70 \mathrm{~cm}$ above the ground, and testing was performed in low diffuse lighting. Each subject was placed in the center of the apparatus and allowed to explore freely for $5 \mathrm{~min}$. An observer scored the number of arm entries made to the open and closed arms as well as time spent in each area.

Open-field task. The round white open-field arena had a diameter of $100 \mathrm{~cm}$ and 55-cm-high sidewalls. The same illumination as in other tasks was used, consisting of indirect diffuse room light (eight $40 \mathrm{~W}$ bulbs, 12 lux). Each subject was released near the wall and observed for 5 $\mathrm{min}$. As in all other tasks, performance in the open field was recorded by a computer-based video tracking system (Analysis VP-200; HVS Image, Hampton, UK). Activity measures included distance traveled, percentage of time spent in active exploration (episodes of movement $\geq 5 \mathrm{~cm} / \mathrm{s}$ ), and 
speed of movement during active exploration. To analyze anxiety levels, the activity measures were broken down into two zones. Based on our previous studies, a $20-\mathrm{cm}$-wide wall zone constituted the most preferred peripheral zone, whereas the rest of the open field was defined as a central zone comprising $\sim 67 \%$ of the arena surface and was most aversive for mice. The number of entries to the central zone of the open field was also recorded.

\section{Electrophysiological studies in hippocampal slices}

Hippocampal slices were prepared from adult (3-6 months old) male BACE1 knock-out or wild-type mice as described previously (Zhao and Lee, 2003). Briefly, under deep anesthesia by halothane, mice were killed by decapitation, and their brains were removed quickly and transferred to the ice-cold dissection buffer containing the following (in $\mathrm{mm}$ ): 212.7 sucrose, $2.6 \mathrm{KCl}, 1.23 \mathrm{NaH}_{2} \mathrm{PO}_{4}, 26 \mathrm{NaHCO}_{3}, 10$ dextrose, $3 \mathrm{MgCl}_{2}$, and $1 \mathrm{CaCl}_{2}$ (bubbled with a mixture of $5 \% \mathrm{CO}_{2}$ and $95 \% \mathrm{O}_{2}$ ). A block of hippocampus was removed and sectioned into $400-\mu \mathrm{m}$-thick slices using a vibratome. The slices were recovered for $1.5 \mathrm{~h}$ at room temperature in artificial CSF (ACSF) (in mM): $124 \mathrm{NaCl}, 5 \mathrm{KCl}, 1.25 \mathrm{NaH}_{2} \mathrm{PO}_{4}, 26$ $\mathrm{NaHCO}_{3}, 10$ dextrose, $1.5 \mathrm{MgCl}_{2}$, and $2.5 \mathrm{CaCl}_{2}$ (bubbled with a mixture of $5 \% \mathrm{CO}_{2}$ and $95 \% \mathrm{O}_{2}$ ). All recordings were done in a submersion recording chamber perfused with ACSF $\left(29.5-30.5^{\circ} \mathrm{C}, 2 \mathrm{ml} / \mathrm{min}\right)$. Synaptic responses were evoked by stimulating the Schaffer collaterals with $0.2 \mathrm{~ms}$ pulses delivered through concentric bipolar stimulating electrodes (Frederick Haer Company, Bowdoinham, ME) and recorded extracellularly in CA1 stratum radiatum. Baseline responses were recorded using half-maximal stimulation intensity at $0.033 \mathrm{~Hz}$. To induce longterm potentiation (LTP), four trains of theta-burst stimulation (TBS) were delivered at $0.1 \mathrm{~Hz}$. Each train consists of 10 bursts (four pulses at $100 \mathrm{~Hz}$ per burst) repeated at $5 \mathrm{~Hz}$ frequency. Long-term depression (LTD) was induced by a paired-pulse $1 \mathrm{~Hz}$ protocol ( $\mathrm{PP}-1 \mathrm{~Hz}$ ) [paired pulses with interstimulus interval (ISI), $50 \mathrm{~ms}$ delivered at $1 \mathrm{~Hz}$ for 15 min). We used three episodes of paired-pulse, $1 \mathrm{~Hz}$ stimulus delivered with $15 \mathrm{~min}$ interepisode intervals to induce the saturated LTD. For measurement of paired-pulse facilitation (PPF), we used ISIs of 25, 50, $100,200,400,1000$, and $2000 \mathrm{~ms}$. Pharmacologically isolated NMDA receptor-mediated synaptic responses were measured using $0 \mathrm{mM} \mathrm{MgCl}$ ACSF with $10 \mu \mathrm{M}$ NBQX. APV at $100 \mu \mathrm{m}$ was added at the end of each experiment to confirm the NMDA receptor-mediated responses.

\section{Generation and injection of lentiviral-small hairpin RNA} for $B A C E 1$

Two short hairpin RNA (shRNA) (sequences shown in supplemental Fig. S4 $A$, available at www.jneurosci.org as supplemental material) were designed according to guidelines described previously (Elbashir et al., 2002; Paddison and Hannon, 2002; Dykxhoorn et al., 2003; Rubinson et al., 2003). The two shRNA specifically target BACE1 mRNA and are predicted not to anneal to any other mRNA in mice as determined by homology search of the mouse database. The shRNAs were subcloned into a lentiviral vector generously provided by Dr. Parijs (Massachusetts Institute of Technology, Cambridge, MA) (Rubinson et al., 2003). The shRNAs were packaged into lentivirus (LV) (Invitrogen) and subsequently concentrated by centrifugation, and its titer $\left(\sim 5.2 \times 10^{5} \mathrm{IU} / \mu \mathrm{l}\right)$ was determined by the expression of green fluorescent protein (GFP) in infected HEK293 cells. HEK293 cells were cultured under standard conditions in DMEM media with $2 \mathrm{mM} \mathrm{L-glutamine} \mathrm{and} 10 \%$ fetal calf serum (Invitrogen). N2A cells were maintained in 45\% DMEM, 45\% OptiDMEM, $10 \%$ fetal calf serum, and 2 mM L-glutamine. N2A cells were transfected with two different short hairpin RNAis, SH1-BACE1 and SH2-BACE1, and, $24 \mathrm{~h}$ later, cells were infected with adenoviral vector expressing APPswe. At $48 \mathrm{~h}$ after transfection, conditioned media were collected, and levels of $A \beta_{1-40}$ were determined by sandwich ELISA (Biosource International).

Using a glass pipette attached to a Hamilton syringe, $3 \mu$ l of high-titer lentivirus expressing either SH1-BACE1 or GFP alone were stereotaxically injected into the right hippocampus of APPswe/PS1 $\triangle E 9$ mice using a syringe pump (New Era Pump System, Farmingdale, NY) at a rate of $0.25 \mu \mathrm{l} / \mathrm{min}$. Two injections were made using the following coordinates (in $\mathrm{mm}$ ): injection 1 , anteroposterior 2.5 , mediolateral 2 , dorsoventral
2.5; and injection 2, anteroposterior 2.5, mediolateral 2.5, dorsoventral 2.5 . For unbiased stereological analysis, every 15 th section of $10-\mu \mathrm{m}-$ thick sections was sampled within $\sim 1 \mathrm{~mm}$ surrounding the injection site and the respective region of the contralateral hippocampus. The amount of $A \beta$ deposits as visualized by immunostaining with antisera specific to ubiquitin in the polymorph layer/CA3 (the path of mossy fibers and their terminals) was determined.

\section{Statistical analyses}

The data were analyzed using repeated measures or simple main effect ANOVAs and two-tailed $t$ test with the statistical package Statistica 6.0 (StatSoft, Tulsa, OK) and a minimal level of significance $p<0.05$. The main factors were as follows: group, a comparison between groups of different genotypes (BACE1 $1^{-/-}$, APPswe;PS1 $\triangle E 9$, APPswe;PS1 $\triangle E 9$; $B A C E 1^{-/-}, A P P s w e ; P S 1 \triangle E 9 ; B A C E 1^{+/-}$, and nontransgenics), and gender. However, comparisons between male and female mice are not reported because there were no significant effects of gender or gender $\times$ group interactions. The repeated measures were as follows: sessions, a comparison between means from trials during sessions, and trials, a comparison between trials. Newman-Keuls post hoc tests were applied to significant main effects or interactions.

\section{Results}

\section{BACE1 selectively accumulates in the CNS}

The relative differences between BACE1 and BACE2 mRNA expression in various tissues (Vassar et al., 1999; Bennett et al., 2000) led us to hypothesize that BACE1 is a major factor in selective predisposition of $\mathrm{A} \beta$ accumulation in the $\mathrm{CNS}$ (Wong et al., 2001). We determined levels and distributions of BACE1 in the CNS compared with these parameters in other organs. In contrast to the ubiquitous expression pattern of BACE1 mRNA in a variety of tissues (Vassar et al., 1999), BACE1 protein accumulates to high levels in the brain (Fig. 1A), although it is undetectable in non-neural tissues, including the pancreas, which had been shown to have the highest levels of expression of BACE1 transcripts (Vassar et al., 1999). In interpreting the protein blots, it is important to note there is a nonspecific cross-reacting band (migrating at slightly higher molecular weight than BACE1) (Fig. $1 A)$. Without the $B A C E 1^{-/-}$tissues as controls, this band could be mistakenly identified as BACE1. To examine the distribution of BACE1 within the brain, we determined the levels of BACE1 in different regions of the newborn (Fig. $1 B$ ) and adult (Fig. $1 C$ ) mouse brains. With the exception of the relatively higher levels of BACE1 in the olfactory bulb, the levels of BACE1 in most regions of the brain appear to be uniform when normalized to the level of $\beta 3$-tubulin (Fig. $1 B, C$ ). Altogether, our results are consistent with the view that the selective accumulation of BACE1 in the brain predisposes the CNS to $\mathrm{A} \beta$ amyloidosis.

Although BACE1 protein is present at comparable levels in most brain regions (Fig. $1 B, C$ ), BACE1-specific immunoreactivities are particularly localized in the hippocampus, a region that is critical for learning and memory and one that is vulnerable in $\mathrm{AD}$ (Fig. 1D). Notably, strong signals were observed in the hilus of dentate gyrus and stratum lucidum of CA3 region (terminal field of mossy fiber pathway) (Fig. $1 D, I$ ). As expected, no specific signals were observed in brain sections prepared from BACE1 knock-out mice (Fig. 1E). To determine whether BACE1 has a presynaptic location, we compared the immunostaining patterns of BACE1 with that of several markers. The pattern of BACE1 immunoreactivity in the hippocampus was remarkably similar to two well characterized presynaptic terminal markers, synaptophysin (Fig. $1 F$ ) and syntaxin 1 (Fig. $1 H$ ). In contrast, the BACE1 pattern was distinct from that of MAP2 (Fig. $1 G$ ), a postsynaptic marker. Moreover, under higher magnification, BACE1 immunoreactivities were localized to the giant boutons of the mossy 


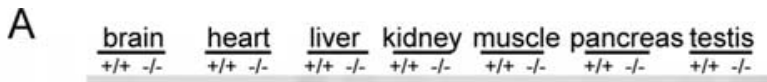

(KD)
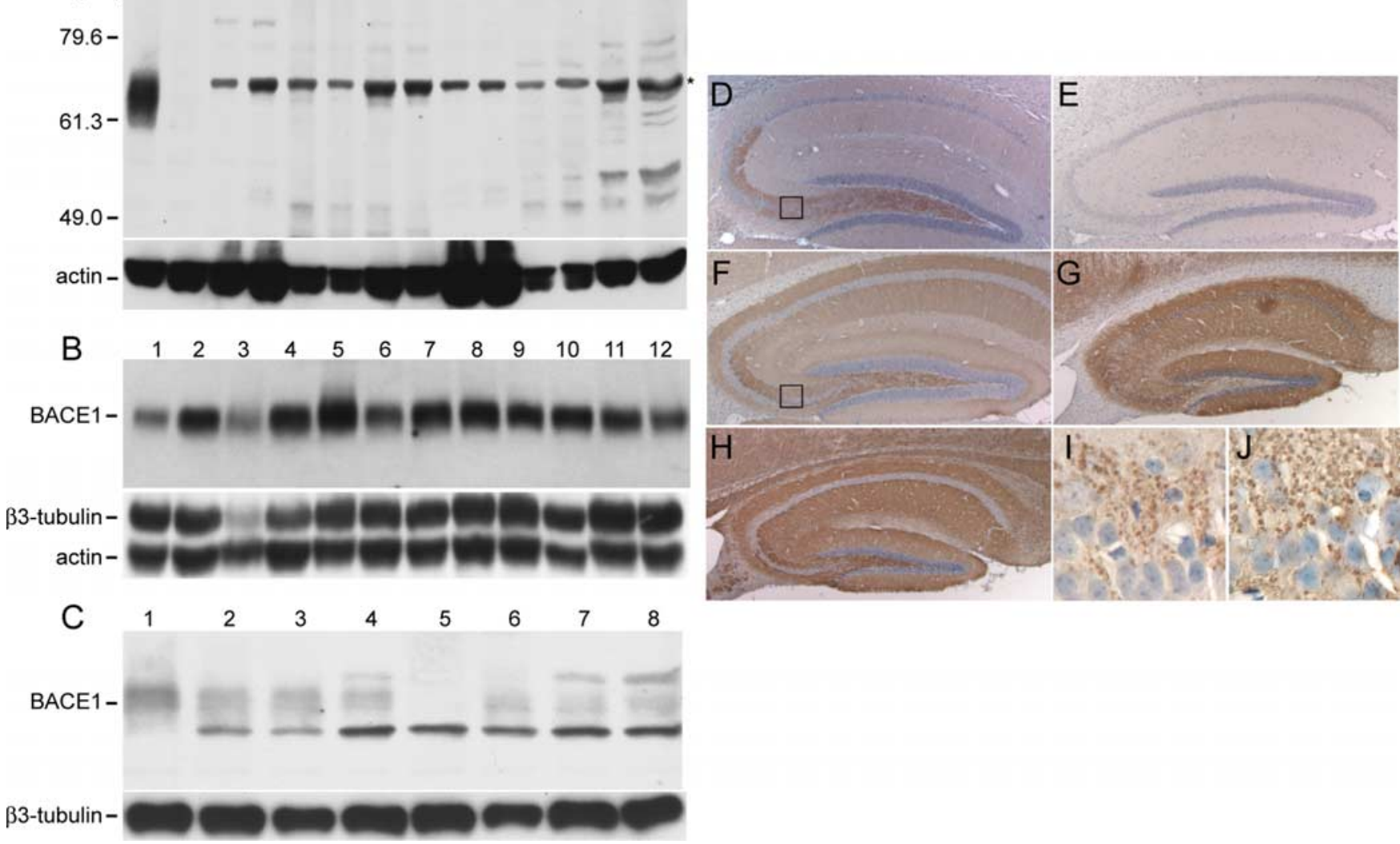

Figure 1. Selective accumulation of BACE1 in the brain. $A$, Protein extracts $\left(50 \mu \mathrm{g}\right.$ each) from different organs of littermate $B A C E 1^{+/+}$and $B A C E 1^{-/-}$mice were immunoblotted with anti-BACE1 fusion protein antibody and reprobed with antisera against actin. Note that BACE1 was most abundant in brain. $B$, Protein extracts (100 $\mu$ g each) from different regions in the CNS of newborn mice (Chemicon) were immunoblotted using the same antiserum against BACE1 as in $\boldsymbol{A}$ and reprobed with antiserum against actin and $\beta 3$-tubulin. 1, Frontal cortex; 2, posterior cortex; 3, cerebellum; 4, hippocampus; 5 , olfactory bulb; 6, striatum; 7, thalamus; 8 , midbrain; 9 , entorhinal cortex; 10 , pons; 11 , medulla; 12 , spinal cord. C, Protein extracts (25 $\mu$ g each) prepared from seven different regions in the CNS of adult mice were used for examining the expression levels of BACE1 protein. As control, the same membrane was stripped and blotted with $\beta 3$-tubulin antibodies. $B A C E 1^{+/+}$tissue from the following: 1 , olfactory bulb; 2 , cortex; 3 , hippocampus; 4, thalamus; 6, cerebellum; 7, brain stem; 8, spinal cord; as a control, cortex from $B A C E 1^{-/-}$was loaded in lane 5. D, E, BACE1 immunoreactivities were localized to the hippocampal hilus of the dentate gyrus and stratum lucidum of $B A C E 1^{+/+}$mice $(\boldsymbol{D}) ;$ no signal was observed in $B A C E 1^{-/-}$mice $(\boldsymbol{E})$. $\boldsymbol{F}-\boldsymbol{H}$, Antibodies specific to synaptophysin $(\boldsymbol{F})$ or syntaxin $1(\boldsymbol{H})$ immunostained the projection of hippocampal axons and their presynapticterminals, whereas the projection of hippocampal dendrites was revealed by MAP2 immunostaining $(G)$ from $B A C E 1^{+/+}$mice. Higher magnification of the boxed area in $\boldsymbol{D}$ and $\boldsymbol{F}$ showed, respectively, BACE1 $(I)$ and synaptophysin $(J)$ immunoreactivities localized to giant boutons of hippocampal mossy fibers. All sagittal sections $(10 \mu \mathrm{m})$ were counterstained with hematoxylin and eosin.

fibers that form synapses with proximal dendrites of CA3 pyramidal cells (Fig. 1I); these giant boutons were readily labeled by anti-synaptophysin antibody (Fig. $1 \mathrm{~J}$ ). Together, these results are consistent with the view that BACE1 is enriched in presynaptic terminals. Because hippocampal granule cells are continuously undergoing turnover throughout the life of the animal, the enrichment of BACE1 in these highly plastic cells suggests that BACE1 may play a role in either synaptic development or plasticity.

Levels of BACE1 activity in neurons is a major determinant of selective predisposition of CNS to amyloidosis

Because cleavages of APP by $\alpha$-secretase and BACE2 (between positions $16-17,19-20$, and $21-22$ of $A \beta$ ) result in truncated non-amyloidogenic peptides, we hypothesized that relative levels of BACE1-mediated activities versus BACE2 and $\alpha$-secretase activities could significantly influence the ability of neurons (in contrast to glial cells) to secrete $A \beta$. To test this hypothesis, we determined the relative levels of protein and enzymatic activities of BACE1, BACE2, and $\alpha$-secretase in primary cortical neurons compared with astrocytes. Whereas levels of BACE1 in neurons are significantly higher than that of astrocytes, levels of BACE2 are higher in glial cells compared with neuronal cultures (Fig. $2 A$ ). To determine the relative secretase activities between neuronal and glial cultures, we coated the SELDI protein chip array with a monoclonal antibody (6E10) that specifically recognizes the $\mathrm{N}$-terminal $1-16$ of $\mathrm{A} \beta$, to monitor simultaneously relative amounts of $\mathrm{A} \beta_{1-40}$ and $\mathrm{A} \beta_{1-42}$ (derived from BACE1 and $\gamma$-secretase cleavages), $A \beta$ fragments 1-19 and 1-20 (generated from BACE1 and BACE2 cleavages), and $A \beta$ fragments $1-15$ and $1-16$ (derived from BACE1 and $\alpha$-secretase cleavages) secreted from conditioned media of cells infected with recombinant adenovirus expressing APPswe (Fig. 2B-E). Consistent with our protein blot analysis, we observed that neurons exhibit lower levels of BACE2 and $\alpha$-secretase generated peptides compared with levels of peptides produced by BACE1 activity. In contrast, astrocytes show higher levels of BACE2 and $\alpha$-secretase activities compared with BACE1 activity (Fig. 2C). Thus, relative amounts of BACE2-dependent $1-19$ and $1-20$ or $\alpha$-secretase-dependent $1-15$ or $1-16 \mathrm{~A} \beta$ fragments when normalized to that of $\mathrm{A} \beta_{1-40}$ reveal that both $\alpha$-secretase and BACE 2 activities are significantly higher in astrocyte cultures compared with cultured neurons 
(Fig. $2 F)(n=14 ; p<0.001$, Student's $t$ test). Because the absence of BACE1 abolished secretion of BACE2-dependent $\mathrm{A} \beta_{1-19}$ and $\mathrm{A} \beta_{1-20}$ peptides (Fig. $2 D$ ), we further conclude that BACE2 cleaves APP in vivo at +19 and +20 sites of $A \beta$ but not at +1 site of $\mathrm{A} \beta$. This observation is consistent with the view that BACE2 serves as an $\alpha$-secretase-like enzyme in cells (Yan et al., 2001). Together, our results demonstrate that neurons are the primary source of $A \beta$ in the brain and that the abundance of BACE1 in neurons is a major susceptibility factor that predisposes the CNS to the formation of $\mathrm{A} \beta$. This theory is supported by studies highlighting the importance of the subcellular site of $A \beta$ generation in the pathogenesis of $\mathrm{AD}$ (Lee et al., 2005) and showing that high levels of BACE1 activity increase $\mathrm{A} \beta$ levels (Bodendorf et al., 2002) and are sufficient to elicit neurodegeneration and neurological decline in vivo (Rockenstein et al., 2005).

\section{BACE1 is critical for cognitive and emotional functions}

Although the deletion of BACE1 did not lead to overt developmental abnormalities, an observation that BACE1 null mice exhibit mild cognitive deficits in the Y-maze task (Ohno et al., 2004) raised the question as to whether BACE1 plays a critical role in learning and memory. We used three different behavioral tasks to assess hippocampus-dependent cognitive function in BACE1 null mice. First, using the Morris water maze task (Morris, 1984; Markowska et al., 1993; Andreasson et al., 2001) to assess spatial reference memory, we observed that 3-month-old $B A C E 1^{-/-}$ mice were able to learn and remember the hidden platform location as efficiently as $B A C E 1^{+/-}$or nontransgenic littermates $\left(F_{(2,31)}=0.22-0.32 ; p>0.7\right)$ (Fig. $\left.3 A, B\right)$. However, 16-monthold $B A C E 1^{-/-}$mice exhibited a significant impairment in spatial reference memory during probe trial measures compared with littermate controls $\left(F_{(1,24)}=8.30 ; p<0.01\right)$ (Fig. 3D). During platform trials, the performances of aged $B A C E 1^{-/-}$mice were not significantly different from nontransgenic mice $\left(F_{(1,24)}=\right.$ $3.64 ; p>0.07$ ) (Fig. $3 C$ ), indicating that they were able to adopt nonspatial strategies in finding the hidden platform. These results indicated that $B A C E 1^{-/-}$mice exhibit an age-dependent deficit in spatial reference memory.

We next used the radial water maze tasks to analyze the impact of BACE1 on spatial working memory (Arendash et al., 2001; Dudchenko, 2004). BACE1 $1^{-/-}$mice were significantly impaired in the radial water maze (Fig. $3 E, F$ ); $B A C E 1^{-/-}$mice made significantly more errors before finding the platform compared with $B A C E 1^{+/-}$mice $\left(F_{(2,31)}=6.03 ; p<0.006\right.$; Newman-Keuls post hoc test, $p<0.005)$ or BACE1 $1^{+/+}$mice (Newman-Keuls post hoc test, $p<0.006)$. This deficit cannot be attributed to differences in visual acuity because 3 -month-old $B A C E 1^{-/-}$mice were not impaired on the classical Morris water maze in which the visual demands are equivalent. Additionally, specific testing of vision in the visual discrimination task showed no differences between $B A C E 1^{-/-}$mice and littermate controls (data not shown). One critical aspect of the radial water maze task is a variable start position randomly assigned to a different arm for each trial. This variability in start position ensures that the task is solved using allocentric, hippocampus-dependent, rather than egocentric, hippocampus-independent, strategies (Eichenbaum et al., 1990; King et al., 2002). Interestingly, when a start position was made invariant across the trials, performances of the $B A C E 1^{-/-}$mice in the radial water maze were normal (Fig. $3 F$ ). Therefore, by reducing the hippocampal demands of the task, the $B A C E 1^{-/-}$ mice were able to perform as well as littermate controls, possibly by using hippocampus-independent strategies to complete the task.

In addition, the Y-maze task was used as an independent method to assess spatial working memory in $B A C E 1^{-1-}$ mice. Similar to the radial water maze, we also observed a deficit in cognitive function in $B A C E 1^{-1-}$ mice as judged by the Y-maze task. Although $B A C E 1^{-/-}$mice visited a similar number of arms as the $B A C E 1^{+/-}$or $B A C E 1^{+/+}$mice $\left(F_{(2,31)}=0.57 ; p>0.50\right)$, $B A C E 1^{-/-}$mice showed significant deficits in arm alternation $\left(F_{(2,31)}=3.67 ; p<0.5\right.$; Newman-Keuls post hoc test, $\left.p<0.05\right)$ (Fig. $3 G$ ), indicating that the ablation of $B A C E 1$ resulted in the 
Morris Water Maze $(3 \mathrm{mo})$

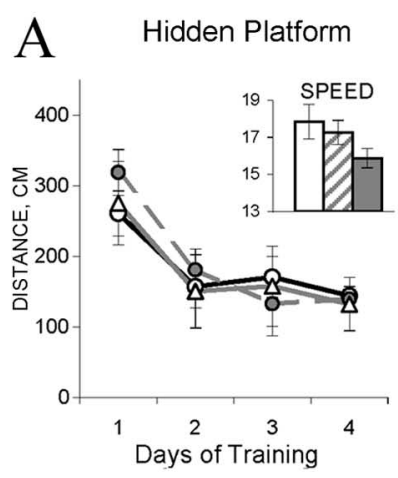

\section{B}

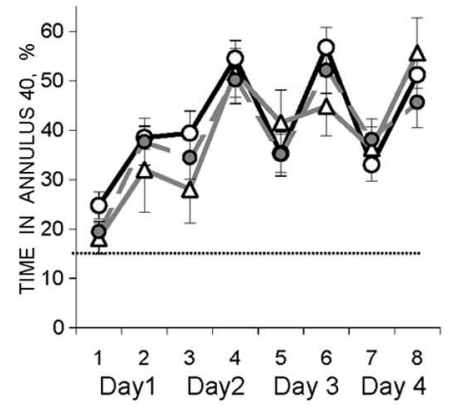

Probe Trials

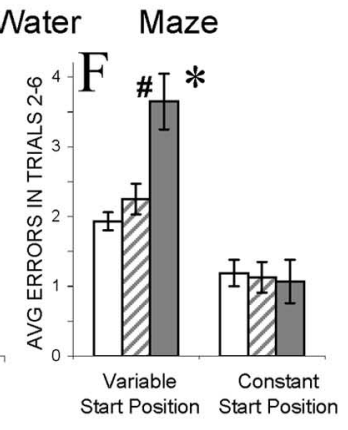

Y Maze
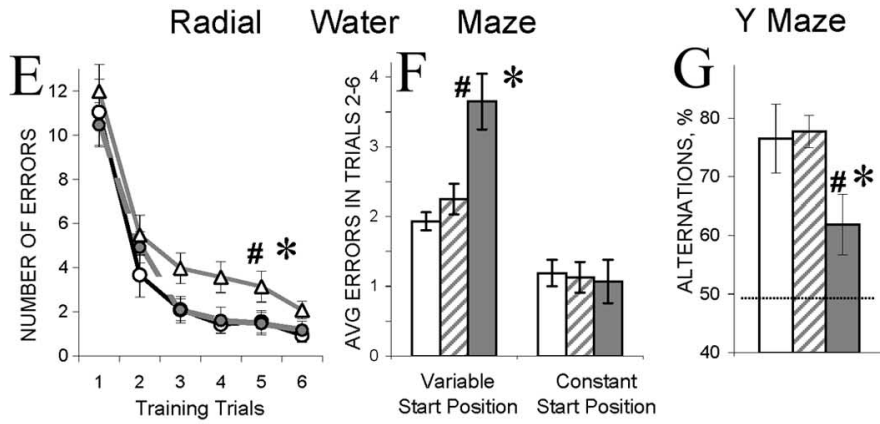

C

Morris Water Maze (16-18 mo)
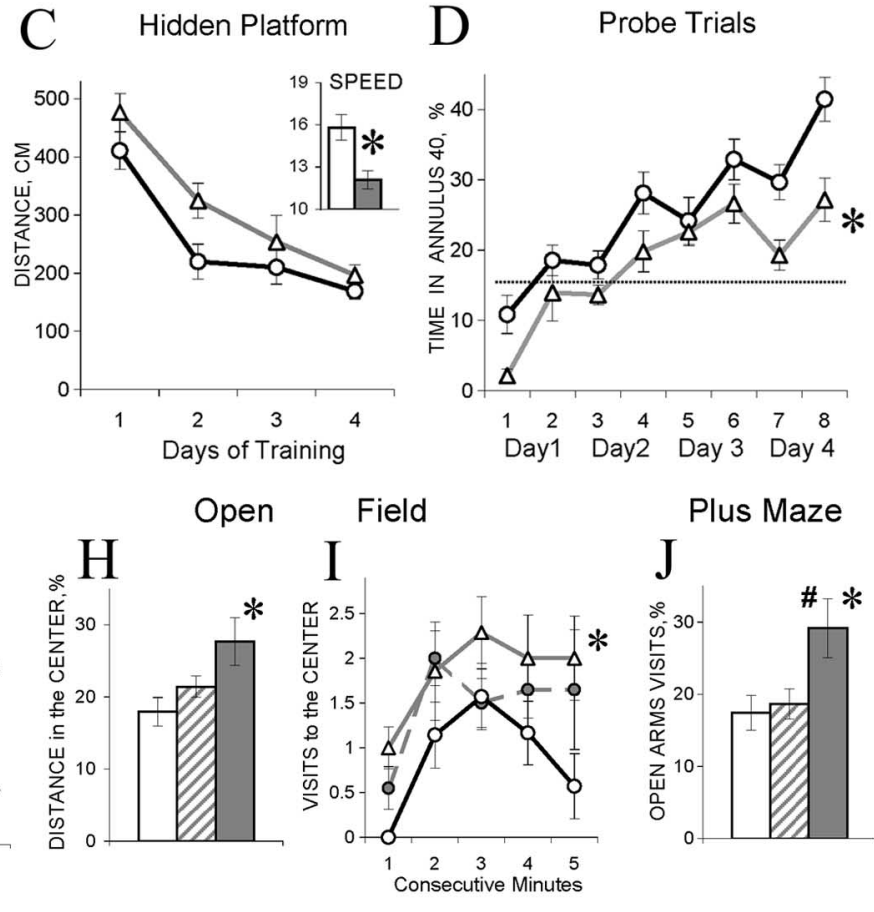

Field
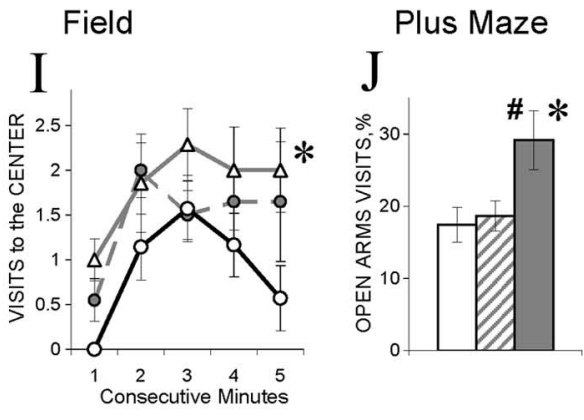

$\square=-0--$ BACE1 $+/-$

BACE1 -/-

Figure 3. Cognitive and emotional deficits in $B A C E 1^{-1-}$ mice. $A-D$, Testing of spatial reference memory in the Morris water maze. Distance to the platform $(A, C)$ and percentage of time spent in annulus 40 around the platform $(\boldsymbol{B}, \boldsymbol{D})$ in 3-month-old $(\boldsymbol{A}, \boldsymbol{B})$ and 16- to 18-month-old $(\boldsymbol{C}, \boldsymbol{D})$ mice. Insets show swim speed averaged for all platform trails. $\boldsymbol{E}$-J, Data for 3-month-old mice. $\boldsymbol{E}$ - $\boldsymbol{G}$, Testing of spatial working memory in 3-month-old mice. Learning of a daily new platform position in the radial water maze $(\boldsymbol{E})$ shown as a number of errors averaged for a $6 \mathrm{~d}$ training for every trial. Number of errors in the radial water maze $(\boldsymbol{F})$ averaged for trials $2-6$; start position for every trial either varied (left columns) or remain constant, allowing the same viewpoint across the trials (right columns). Percentage of spontaneous arms alternation in the Y-maze task is indicated (G). $\boldsymbol{H}$-J, Testing of anxiety in 3-month-old mice. Percentage of distance traveled in the central (more aversive) parts of the open field $(\boldsymbol{H})$. Dynamics of visits to the center during a 5 min test $(\boldsymbol{I})$. Percentage of visits to the open arm of the plus maze $(\boldsymbol{J})$. The asterisks and pound signs $(\boldsymbol{C}-\boldsymbol{J})$ indicate significant differences $(p<0.05)$ from control and $B A C E 1^{+/-}$mice, respectively, as a result of Newman-Keuls post hoc tests applied to significant effect of genotype (ANOVAs, $\left.p<0.05\right)$. Dotted lines show chance levels of performance $(\boldsymbol{B}, \boldsymbol{D}, \boldsymbol{G})$. A table summarizing these behavioral findings is available in supplemental Figure S3 (available at www.jneurosci.org as supplemental material). NTG, Nontransgenic mice.

early cognitive deficits in spatial working memory. Together, these findings support the view that BACE1 plays a critical role in both spatial reference memory and working memory.

$B A C E 1^{-1-}$ mice exhibited a reduced speed of swimming compared with littermate controls (Fig. $3 A, C$ ) in the Morris water maze task, suggesting that anxiety levels in these mice might be reduced because swim speed in rodents may reflect a stress/anxiety reaction to the placement in cold water (Winocur and Hasher, 2004). To test this hypothesis, an open-field task, a popular model of anxiety-like behaviors (Crawley, 1999; Prut and Belzung, 2003), was used to confront animals with an unknown environment. In such a situation, mice spontaneously prefer the periphery of the apparatus (thigmotaxis) as a result of an anxietyinduced inhibition of exploration in the aversive central parts of the open field. An increase in time spent, distance traveled, and number of entries to the central part, as well as a decreased latency to enter the central part, would indicate anxiolysis. In the openfield task, $B A C E 1^{-1-}$ mice traveled a significantly longer distance $\left(F_{(2,31)}=3.45 ; p<0.5\right.$; Newman-Keuls post hoc test, $\left.p<0.05\right)$ and showed a significantly higher proportion of activity $\left(F_{(2,31)}=\right.$ 3.85; $p<0.5$; Newman-Keuls post hoc test, $p<0.05$ ) (Fig. $3 H$ ) and number of visits $\left(F_{(2,31)}=3.68 ; p<0.5\right.$; Newman-Keuls post hoc test, $p<0.05$ ) (Fig. 3I) in the central parts of the open field compared with $B A C E 1^{+/-}$or $B A C E 1^{+/+}$mice. This "low anxi- ety" phenotype was also confirmed in the plus maze in which 3-month-old $B A C E 1^{-1-}$ mice visited open arms of the maze more often compared with $B A C E 1^{+/-}$mice or littermate controls $\left(F_{(2,31)}=4.07 ; p<0.5 ;\right.$ Newman-Keuls post hoc test, $\left.p<0.03\right)$ (Fig. $3 J$ ). Collectively, our findings are consistent with the view that BACE1 null mice exhibit a lower level of anxiety compared with control littermates, implicating an important role for BACE1 in emotion.

\section{$B A C E 1^{-/-}$mice exhibit specific deficit in synaptic plasticity}

To investigate the role of BACE1 in synaptic transmission and plasticity, we used young $B A C E 1^{-1-}$ mice (3-6 months old) and focused on area CA1, one of the main integral outputs from the hippocampus. Parameters of basal synaptic transmission, which predominantly measure the AMPA receptor-mediated component, were not different between wild-type and $B A C E 1^{-1-}$ mice (Fig. 4A). Pharmacologically isolated NMDA receptor-mediated responses were similar between wild-type and $B A C E 1^{-1-}$ mice (Fig. $4 B$ ). We then examined whether presynaptic function is altered in $B A C E 1^{-/-}$mice by measuring the PPF ratio. Interestingly, we found that there is a significant increase in the PPF ratio in $B A C E 1^{-1-}$ mice compared with littermate controls (Fig. $4 C$ ) at $50 \mathrm{~ms}$ interstimulus interval (PPF ratio at $50 \mathrm{~ms}$ ISI: $B A C E 1^{+/+}$, 
$1.59 \pm 0.03, n=40$ slices, 12 mice; $B A C E 1^{-/-}, 1.75 \pm 0.06, n=43$ slices, 12 mice; Fisher's PLSD post hoc analysis, $p<$ $0.02)$. Because changes in PPF ratio have been attributed to alterations in presynaptic release probability (Manabe et al., 1993; Saura et al., 2004), the increased PPF ratio observed in $B A C E 1^{-/-}$mice may indicate a deficit in presynaptic release.

To determine whether synaptic plasticity is altered in the $B A C E 1^{-/-}$mice, we examined LTP using four trains of TBS. We found that there is no difference in the magnitude of LTP up to $2 \mathrm{~h}$ after the TBS protocol $\left(B A C E 1^{+/+}, 165 \pm 11 \%\right.$ at $2 \mathrm{~h}$ after TBS, $n=18$ slices, 10 mice; $B A C E 1^{-/-}, 151 \pm 10 \%, n=7$ slices, 5 mice) (Fig. 5A). Similarly, we did not find a deficit in LTD induced with one train of paired-pulse $1 \mathrm{~Hz}$ protocol $(\mathrm{PP}-1 \mathrm{~Hz}, 15$ min, ISI $=50 \mathrm{~ms})\left(B A C E 1^{+/+}: 75 \pm 4 \%\right.$ at $1 \mathrm{~h}$ post-onset of $\mathrm{PP}-1 \mathrm{~Hz}, n=12$ slices, 5 mice; $B A C E 1^{-/-}: 78 \pm 5 \%, n=12$ slices, 5 mice) (Fig. $5 B$ ). Because one episode of PP-1 Hz does not saturate LTD, we repeated the study with 3 trains of PP- $1 \mathrm{~Hz}$ to determine whether the "lower ceiling" of synaptic plasticity has changed in $B A C E 1^{-1-}$ mice. As shown in Figure $5 C$, we did not find a difference between control and $B A C E 1^{-/-}$mice $\left(B A C E 1^{+/+}\right.$: $58 \pm 4 \%$ at $1 \mathrm{~h}$ post onset of last PP- $1 \mathrm{~Hz}$, $n=16,7$ mice; $B A C E 1^{-/-}: 63 \pm 6 \%, n=18,8$ mice). To determine whether LTD reversal (de-depression) is affected in $B A C E 1^{-/-}$mice, we delivered four trains of TBS after LTD saturation. Surprisingly, we found that $B A C E 1^{-/-}$mice produced a significantly larger de-depression compared with control mice $\left(B A C E 1^{+/+}, 168 \pm 16 \%\right.$ at $30 \mathrm{~min}$ after TBS, $n=13$ slices, 7 mice; $B A C E 1^{-/-}, 252 \pm 27 \%, n=13$ slices, 7 mice; Student's $t$ test, $p<0.01$ ) (Fig. 5D). Both LTP and de-depression are induced by the same TBS protocol, but our data indicate that $B A C E 1^{-/-}$ mice show a selective increase in de-depression. To determine whether this is attributable to differential summation of responses during TBS, we compared the area under the field potentials during the TBS (Fig. $5 E$ ). We found a significant increase in responses during TBS in the $B A C E 1^{-/-}$only during the dedepression (ANOVA, repeated measures, $F_{(1,23)}=6.573 ; p<$ 0.02 ) (Fig. 5E). Collectively, our results indicate that $B A C E 1^{-/-}$ mice display specific deficits in paired-pulse facilitation and dedepression, implicating significant alterations in mechanisms of presynaptic release and synaptic plasticity.

\section{Deletion of $B A C E 1$ prevents age-dependent cognitive deficits occurring in APPswe;PS1 $\triangle E 9$ mice}

Although it has been shown that deletion of $B A C E 1$ prevents both $\mathrm{A} \beta$ deposition (Luo et al., 2003) and cognitive impairment in young APPswe mice (Ohno et al., 2004), an important question is whether, in aged animals, the absence of BACE1 prevents $A \beta$ amyloidosis and age-dependent cognitive deficits. Another critical question that has not been addressed is whether partial reduction of BACE1 ameliorates $\mathrm{A} \beta$ amyloidosis and cognitive impairments in aged mutant APP mice. To address these questions, we used the Morris water maze task, which is sensitive to age-associate cognitive deficits in different mutant APP transgenic models (Ashe, 2001), including our APPswe;PS1 $\triangle E 9$ mice (Savonenko et al., 2005). We initially crossbred $B A C E 1^{-1-}$ mice with $A P P s w e ; P S 1 \triangle E 9$ mice to generate $A P P s w e ; P S 1 \triangle E 9$ mice with normal levels of BACE1 (APPswe;PS1 $\triangle E 9 ; B A C E 1^{+/+}$), with $50 \%$ of normal BACE1 levels (APPswe;PS1 $\triangle E ; B A C E 1^{+/-}$), and without BACE1 (APPswe; $\left.P S 1 \triangle E 9 ; B A C E 1^{-1-}\right)$. Immunocytochemical and biochemical analyses of the resulting offspring are presented in supplemental Figures S4 and S5 (available at www.jneurosci.org as supplemental material). Briefly, APP- $\beta C T F, A \beta_{1-40}$ and $A \beta_{1-42}$ and $A \beta$ deposits are abolished in brains of APPswe;PS1 $E$ E9;BACE1 ${ }^{-/-}$ mice.

We next analyzed the cognitive effects of $B A C E 1$ ablation in 16- to 18 -month-old APPswe;PS1 $\triangle E 9$ mice with 0,50 , or $100 \%$ of BACE1 activity. As expected, APPswe;PS1 $1 E 9$ mice swam a significantly longer distance to find the platform (Fig. 6A) (Newman-Keuls post hoc test, $p<0.0001$ applied to significant effect of group, ANOVA, $\left.F_{(4,63)}=7.69, p<0.0001\right)$ and spent less time in the vicinity of the platform (Fig. 6C,D) (probe trials, NewmanKeuls post hoc test, $p<0.0005$; effect of group, ANOVA $F_{(4,63)}=$ 5.49, $p<0.001)$ than control nontransgenic mice. However, $A P P s w e ; P S 1 \triangle E 9 ; B A C E 1^{-1-}$ mice performed as well as nontransgenic mice in both platform (Fig. 6A) and probe (NewmanKeuls post hoc test, $p>0.35$ ) trials (Fig. $6 C, D$ ), indicating that deletion of $B A C E 1$ prevented age-dependent cognitive deficits observed in APPswe/PS1 1 E9 mice. However, partial decrease of BACE1 to $50 \%$ of normal levels was not sufficient to ameliorate cognitive deficits because APPswe;PS1 $\triangle E 9 ; B A C E 1^{+/-}$mice were significantly impaired compared with nontransgenic controls (Newman-Keuls post hoc test, $p<0.0001$ for platform and probe trial measures) and indistinguishable from APPswe;PS1 $\triangle E 9$ mice 

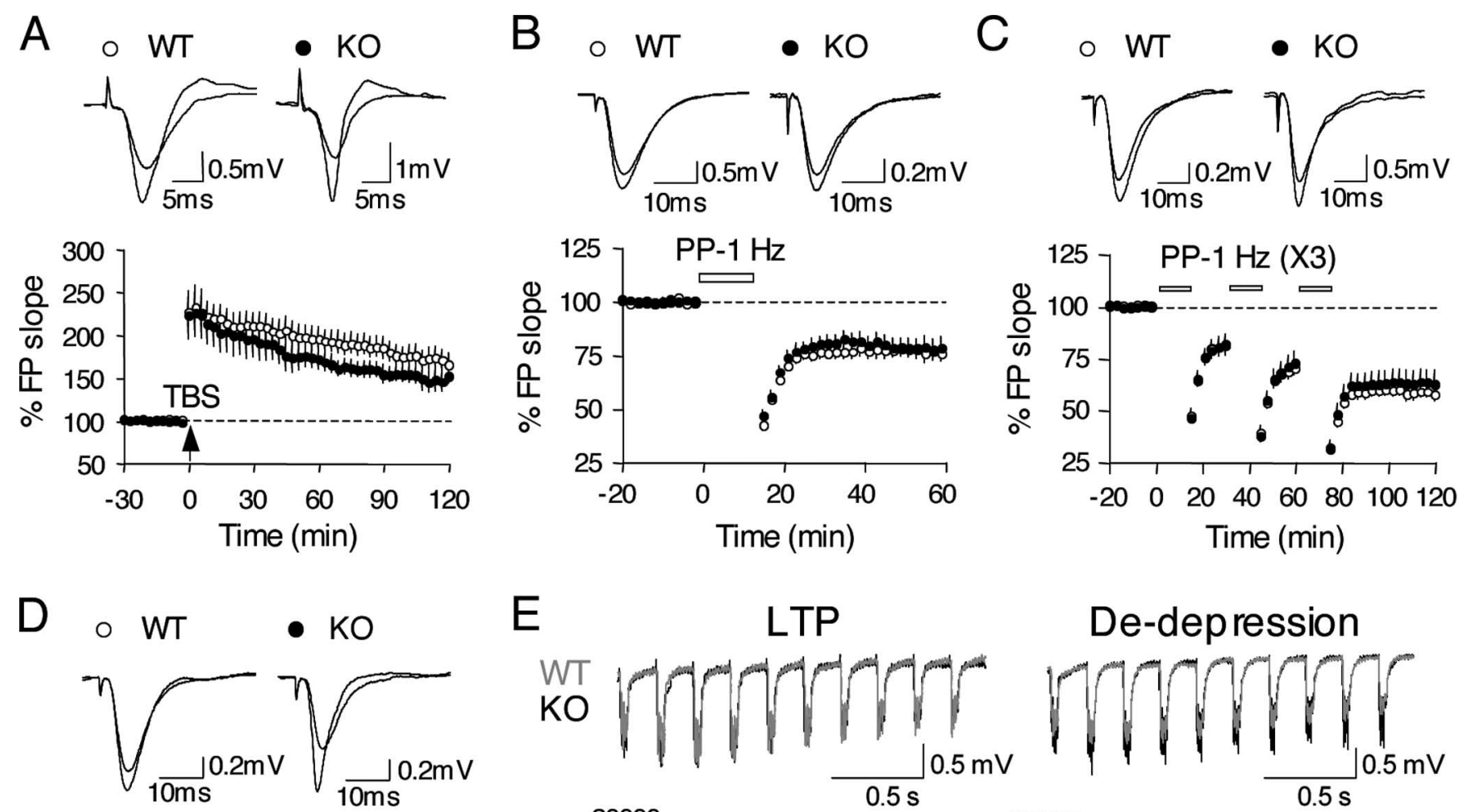

\section{De-depression}
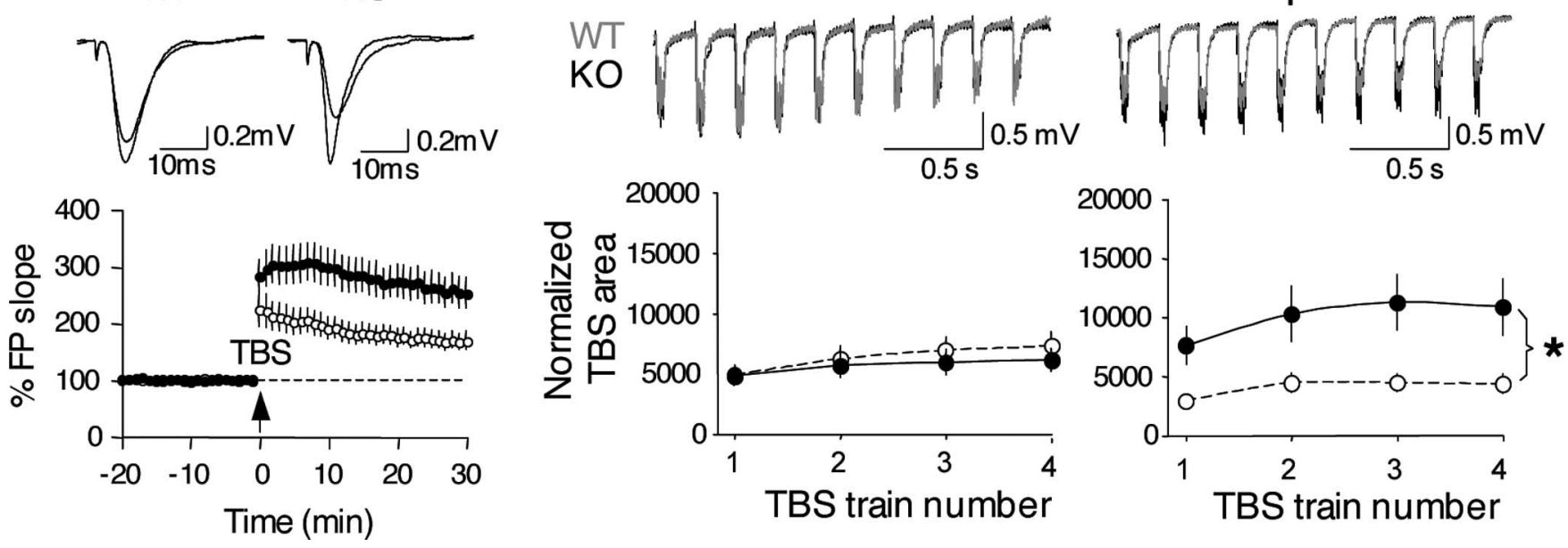

Figure 5. Synaptic plasticity in $B A C E 1^{-/-}$mice. $A$, No change in $L T P$ in $B A C E 1^{-/-}$mice. Grouped averages are shown on the left graph. There is no difference in $L T P$ magnitude in $B A C E 1^{-/-}$mice (filled circles) compared with $B A C E 1^{+/+}$mice (open circles). Example field potential traces taken before and $2 \mathrm{~h}$ after $\mathrm{TBS}$ are overlapped and shown in the right panel for both $B A C E 1^{+/+}$mice (left) and $B A C E 1^{-/-}$mice (right). $\boldsymbol{B}$, No change in LTD in $B A C E 1^{-/-}$mice. LTD induced by PP-1 $\mathrm{Hz}$ (15 min, ISI of $50 \mathrm{~ms}$ ) are shown for $B A C E 1^{+/+}$mice (open circles) and $B A C E 1^{-/-}$mice (filled circles). Example field potential traces taken before and $1 \mathrm{~h}$ after the onset of PP- $1 \mathrm{~Hz}$ are shown in the right panel. $C$, No difference in LTD saturation in BACE1 ${ }^{-1-}$ mice. Three episodes of PP- $1 \mathrm{~Hz}$ (15 min, ISI of $50 \mathrm{~ms}$ ) were repeated at $15 \mathrm{~min}$ intervals to saturate $L T D$ in both $B A C E 1^{+/+}$mice (open circles) and $B A C E 1^{-/-}$mice (filled circles). Top panel shows example field potential traces taken from the baseline and $1 \mathrm{~h}$ after the onset of the third PP-1 Hz overlapped for both $B A C E 1^{+/+}$mice (left) and $B A C E 1^{-/-}$mice (right) for comparison. $D$, Larger de-depression (LTD reversal) in the $B A C E 1^{-/-}$mice. After the saturation of LTD (shown in C), TBS was delivered to induce de-depression. Bottom panel shows the average data in which $B A C E 1^{-/-}$mice (filled circles) show a significantly larger de-depression compared with $B A C E 1^{+/+}$mice (open circles). Baseline in this graph was renormalized to the 20 min before TBS for better comparison. Example traces taken before TBS and 30 min afterward are overlapped for comparison for $B A C E 1^{+/+}$mice (left) and $B A C E 1^{-/-}$mice (right). $E$, Larger summation of TBS responses only during the de-depression in the $B A C E 1^{-/-}$mice. Responses during TBS were compared between $B A C E 1^{+/+}$and $B A C E 1^{-/-}$during $\mathrm{LTP}$ and de-depression induction. Top panel shows example traces taken from the first train of TBS. The traces were taken to match the initial field potential size. Traces from $B A C E 1^{+/+}$(gray lines) and traces from $B A C E 1^{-/-}$(black lines) are overlapped for comparison. Note larger responses in $B A C E 1^{-1-}$ during the de-depression. To quantify these differences, the area under the TBS responses were calculated and normalized to the area under a single field potential (bottom panel). There was a significant increase in the normalized TBS area from the $B A C E 1^{-/-}$mice only during the de-depression compared with $B A C E 1^{+/+}$mice. The asterisk indicates statistically significant difference in normalized TBS area during all four TBS trains. KO, Knock-out mice; WT, wild-type mice.

$(p>0.77$ ) (Fig. 6A,C,D). Together, these results demonstrate that complete deletion of BACE1 prevents age-related cognitive deficits occurring in a mouse model of $\mathrm{A} \beta$ amyloidosis, but a $50 \%$ decrease of BACE1 is not sufficient to significantly ameliorate cognitive deficits.

Cognitive deficits occurring in $B A C E 1^{-/-}$mice are prevented by $A P P$ and $P S 1$ transgenes

We have already shown that BACE1 null mice exhibited an agedependent cognitive deficit (see above) (Fig. $3 C, D$ ) as assessed by the Morris water maze. Intriguingly, the memory impairments observed during probe trials in $B A C E 1^{-/-}$mice did not occur in
APPswe;PS1 $\triangle E 9 ; B A C E 1^{-/-}$mice (Fig. $6 C, D$ ), indicating that the BACE1-dependent cognitive deficits are attenuated by coexpression of $A P P$ and $P S 1$ transgenes. Importantly, despite the rescue of cognitive impairments in $B A C E 1^{-/-}$mice overexpressing $A P P$ and $P S 1, B A C E 1^{-/-}$mice showed a slower swim speed when compared with nontransgenic controls, APPswe;PS1 $1 E 9$, or $A P P s w e ; P S 1 \triangle E 9 ; B A C E 1^{+/-}$mice (Fig. $6 A, B$ ). These results indicated that, in contrast to cognitive deficits, a "low swim speed" phenotype was associated with the deletion of BACE1 and appeared to be independent of coexpression of APP and PS1 transgenes. The low swim speed phenotype was observed in both hidden and visible platform trials (Fig. $6 A, B$ ), suggesting that this 
A

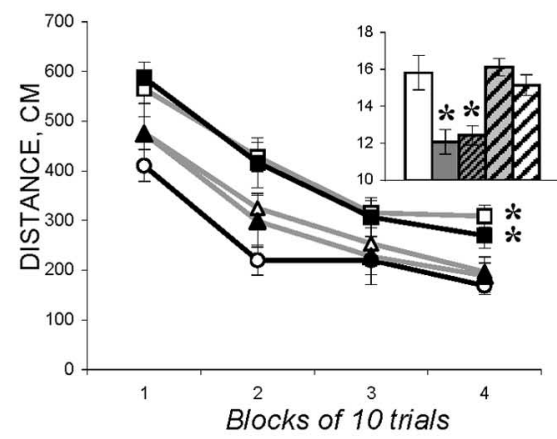

D
B

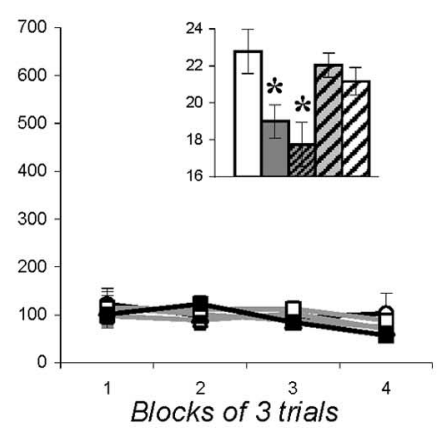

$\mathbf{E}$
C

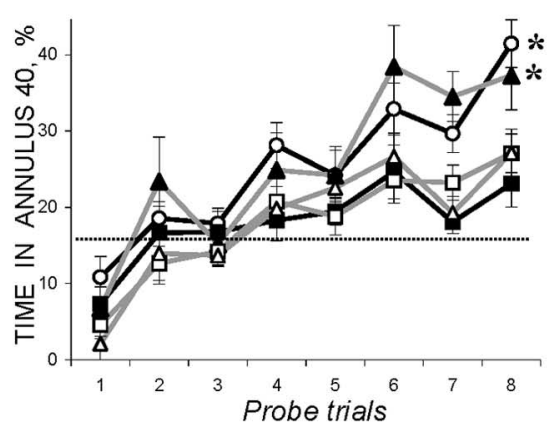

$\mathbf{F}$

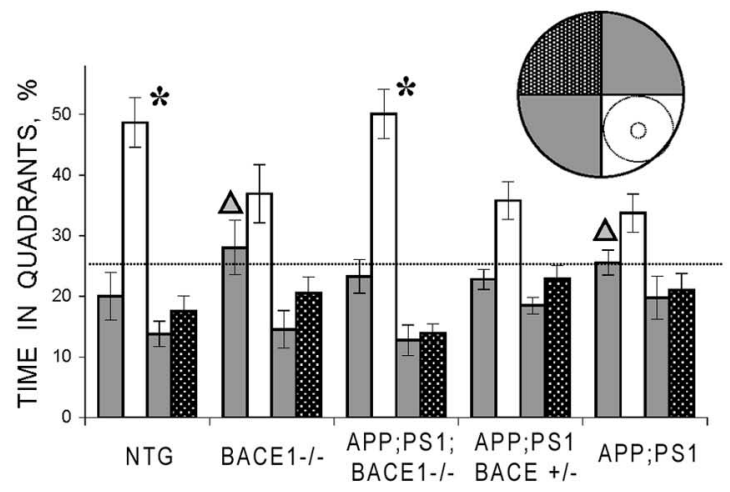

G
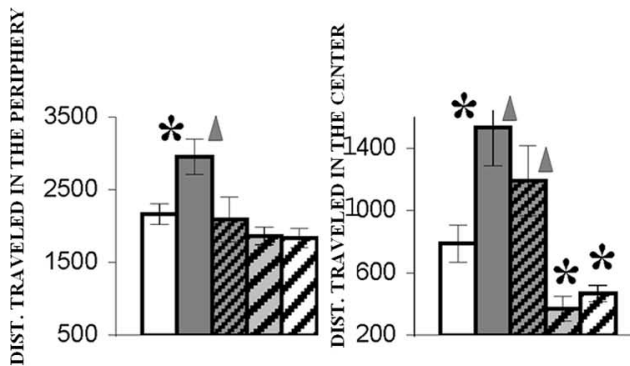

H

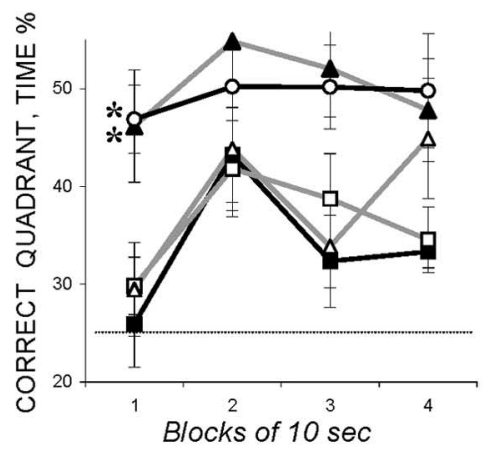

Blocks of 10 sec

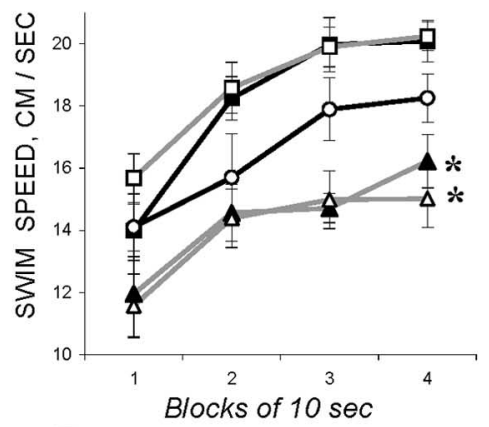

I
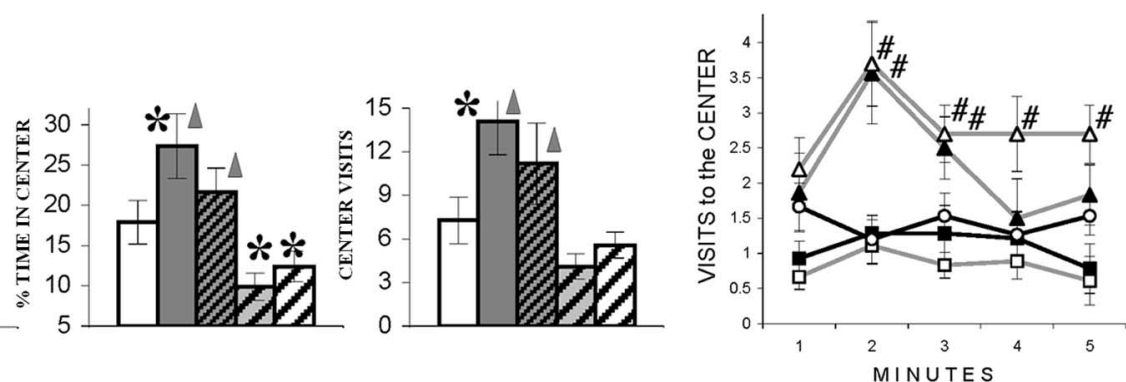

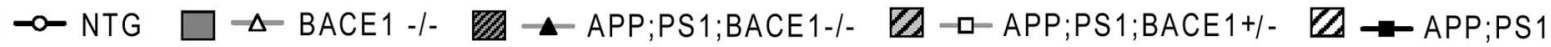

Figure 6. Analyses of cognitive and emotional behaviors in aged $B A C E 1^{-/-}, A P P S W e ; P S 1 \triangle E 9$, and $A P P S W e ; P S 1 \triangle E 9 ; B A C E 1^{-/-}$mice. $A-\boldsymbol{F}$, Cognitive deficits present in aged (16-18 months) $B A C E 1^{-1-}$ and $A P P S w e ; P S 1 \triangle E 9$ mice but absent in APPswe;PS1 $E$ E; BACE1 ${ }^{-1-}$ mice. Distance to find the platform is shown for consecutive blocks of "platform" trials in which the platform was available but hidden under the milky water $(\boldsymbol{A})$. Inset shows an average swimming speed during platform trials. Note that $B A C E 1^{-/-}$and $A P P S W e ; P S 1 \triangle E 9 ; B A C E 1^{-/-}$mice swam significantly slower than all other groups. No between-group differences were observed in distance to find the platform when it was made visible by a high-contrast extension $(B)$. Inset shows that $B A C E 1^{-/-}$ and $A P P$ swe; $P S 1 \triangle E 9 ; B A C E 1^{-1-}$ mice swim slower than other groups similar to that observed in hidden platform trials (see $A$ ). Spatial preferences for the hidden platform location tested in the "probe" trials $(\boldsymbol{C}-\boldsymbol{F})$ in which the platform was lowered and inaccessible for the mouse for a variable interval ( $30-40 \mathrm{~s})$. Acquisition of spatial preference is shown as a percentage of time spent in annulus 40 in consecutive probe trials $(C)$ conducted before and after each block of 10 platform trials (shown in $\boldsymbol{A}$ ). Nontransgenic controls and $A P P$ Swe;PS1 $D E 9 ; B A C E 1^{-/-}$mice acquired significantly higher preference for the platform location compared with all other groups. Percentage of time spent in different quadrants of the water maze during the last probe trial ( $\boldsymbol{D})$. Inset in $\boldsymbol{D}$ shows the scheme of quadrants in the water maze. The small circle indicates the location of the hidden platform, and the larger circle shows a borderline of annulus 40 , an area of $40 \mathrm{~cm}$ in diameter centered around the platform. Nontransgenic and $A P P_{S W e} ; P S 1 \triangle E 9 ; B A C E 1^{-1}{ }^{-}$mice swam predominantly in the correct quadrant (white bars), whereas the spatial preferences in other groups were significantly lower and distributed between the correct and one of the adjacent (gray bars) quadrants. The triangles indicate that the preferences for the correct and one of the adjacent quadrants are not different $(p>0.2)$. Preference for the correct quadrant is shown in consecutive blocks of $10 \mathrm{~s}$ in the last probe trial $(\boldsymbol{E})$. The spatial preferences were stable in nontransgenic and APPswe;PS1 $1 E 9 ; B A C E 1^{-/-}$mice but not in other groups. In all genotypes, swim speed increased in the course of the probe trial $(\boldsymbol{F}) . B A C E 1^{-/-}$and $A P P S w e ; P S 1 \triangle E 9 ; B A C E 1^{-/-}$mice swam consistently slower than other groups (see also insets in $\boldsymbol{A}$ and $\boldsymbol{B}$ ). The asterisks in $\boldsymbol{A}$ and $\boldsymbol{C}-\boldsymbol{F}$ indicate a significant difference from other groups as determined by Newman-Keuls post hoc test applied to a significant effect of group (ANOVA, $p<0.05$ ). Dotted lines in $\boldsymbol{C}-\boldsymbol{E}$ show chance levels of performance for the variables used. $\mathbf{G}-\boldsymbol{I}$, Anxiolytic phenotypes present in $B A C E 1^{-1-}$ and APPSwe;PS1 $\triangle E 9 ; B A C E 1^{-1-}$ mice in the open-field test. Integral measures of activity $(\boldsymbol{G})$ and anxiety $(\boldsymbol{H})$ averaged for whole duration of testing $(5 \mathrm{~min})$ is shown. The asterisks and triangles indicate a significant difference from nontransgenics (NTG) and $A P P S$ Swe; PS1 $\triangle E 9$ mice, respectively, as a result of Newman-Keuls post hoc test applied to significant effect of group (ANOVAs, $p<0.01$ ). Note that $B A C E 1^{-/-}$and $A P P S W e ; P S 1 \triangle E 9$ mice had contrasting deficits in distance, time, and number of visits to the central part of the open field, indicating low and high anxiety levels, respectively. Dynamics of visits to the central part of the open field $(I)$ are shown for consecutive minutes of testing. Pound signs indicate significant differences from nontransgenic group as a result of Newman-Keuls post hoc test $(p<0.05)$ applied to significant group $\times$ minute interaction (ANOVA, $F_{(16,252)}=1.75 ; p<0.05$ ). 
behavioral trait of mice lacking BACE1 was independent of cognitive demands of the tasks.

To further delineate a possible interaction between spatial memory and swim speed in $B A C E 1$ knock-out mice, we evaluated in greater detail the last probe trial in which between-group differences were most robust (Fig. $6 D-F$ ). In the probe trial, the swimming speeds of $B A C E 1^{-/-}$mice (with or without mutant $A P P ; P S 1$ transgenes) were significantly lower than those found in other groups (Fig. $6 F$ ) (effect of group, $F_{(4,63)}=4.50 ; p<0.005$ ). Importantly, the swim speed of $B A C E 1^{-{ }^{-}}$mice increased over the course of the probe trials, indicating that the low swim speed was not simply a result of fatigue (which would be observed as a reduced swim speed as the probe trials progressed) (effect of $10 \mathrm{~s}$ blocks, $F_{(3,252)}=17.15 ; p<0.0001$; group $\times$ block interaction is not significant). Comparisons of swim speeds and spatial preferences between $B A C E 1^{-/-}$mice with or without mutant APP;PS1 transgenes showed that, despite having similar swim speeds, these two groups were significantly different in their preferences for the correct quadrant (Fig. 6E,F). Together, our results indicated that, in the observed range of changes, the swim speeds did not interfere with the spatial performance during probe trials. Thus, spatial memory deficits observed in $B A C E 1^{-1-}$ mice appeared to be independent of alterations in swim speeds and could be prevented by coexpression of mutant $A P P ; P S 1$ transgenes, implicating an important role for the APP processing pathway in cognition.

\section{Dissociation between cognitive and emotional deficits in $B A C E 1^{-/-}$mice}

Although cognitive deficits occurring in $B A C E 1^{-/-}$mice were prevented by coexpression of APP;PS1 transgenes, we next assessed the impact of these transgenes on the emotional alteration observed in $B A C E 1^{-1-}$ mice. We used the open-field task to assess the anxiety level in mutant $A P P ; P S 1$ mice lacking $B A C E 1$. As observed previously for young $B A C E 1^{-/-}$mice (Fig. 3), 16- to 18-month-old $B A C E 1^{-/-}$mice traveled a significantly longer distance and showed a significantly higher proportion of activity and number of visits in the central parts of the open field compared with nontransgenic controls (ANOVAs, $F_{(4,63)}=6.90-$ $10.56, p<0.005$; Newman-Keuls post hoc tests, $p<0.03$ ), indicating a low level of anxiety (Fig. $6 G-I$ ). In contrast to $B A C E 1^{-/-}$ mice, APPswe;PS1 $\triangle E 9$ mice spent less time and traveled a shorter distance in the central parts of the open field than nontransgenic mice (Newman-Keuls post hoc test, $p<0.05$ ) (Fig. 6G-I). Importantly, the differences between APPswe;PS1 $1 E 9$ mice and nontransgenic mice were observed exclusively in the central but not peripheral (relatively safe) parts of the open field (Fig. 6G). These behavioral traits are typical of high anxiety rather than low motor activity. Thus, in the open-field task, $B A C E 1^{-/-}$mice and APPswe;PS1 $1 E 9$ mice showed contrasting emotional deficits with low and high anxiety levels, respectively.

Given that the cognitive deficits occurring in BACE1 null mice and $A P P s w e ; P S 1 \triangle E 9$ mice were prevented in APPswe;PS1 $\triangle E 9$ mice lacking $B A C E 1$, one may expect that a similar interaction be observed for emotional deficits. However, anxiety measures in $A P P s w e ; P S 1 \triangle E 9 ; B A C E 1^{-1-}$ mice did not support this assumption because, in all anxiety measures, $A P P$ swe; $P S 1 \triangle E 9 ; B A C E 1^{-\prime-}$ mice were significantly different from APPswe;PS1 $\triangle E 9$ mice (Newman-Keuls post hoc tests, $p<0.05$ ) but not from $B A C E 1^{-/-}$ mice (Fig. 6G). Furthermore, APPswe;PS1 $\triangle E 9 ; B A C E 1^{-/-}$mice closely mimicked the low anxiety phenotype observed in $B A C E 1^{-/-}$mice, particularly at the beginning of testing in a novel environment (Fig. 6I). Altogether, these results indicated that, whereas cognitive deficits occurring in $B A C E 1^{-/-}$mice were prevented in APPswe;PS1 $\triangle E 9 ; B A C E 1^{-1-}$ mice, the emotional phenotypes of $B A C E 1^{-/-}$mice (low anxiety levels) were not ameliorated by coexpression of mutant $A P P ; P S 1$ transgenes.

\section{$\mathrm{A} \boldsymbol{\beta}$ deposition is sensitive to $B A C E 1$ dosage and efficiently cleared from brains of aged APPswe;PS1 $\triangle E 9$ mice}

Because of the potential value of inhibiting BACE1 in efforts to ameliorate $\mathrm{A} \beta$ deposition in $\mathrm{AD}$, we examined the following: (1) the relationships between the levels of BACE1 protein and amounts of $\mathrm{A} \beta$ production/deposition in our lines of mice, including $B A C E 1^{+/-}$mice that express $50 \%$ of normal level of BACE1 protein; and (2) whether silencing BACE1 through RNA interference (RNAi) ameliorates $\mathrm{A} \beta$ deposition in the hippocampus of a mouse model of amyloidosis. To determine whether $\mathrm{A} \beta$ burden is sensitive to dosage of $B A C E 1$ in the CNS, we initially assessed $\mathrm{A} \beta$ production in young $A P P s w e ; P S 1 \triangle E 9 ; B A C E 1^{+/+}$ and $A P P$ swe;PS1 $\triangle E 9 ; B A C E 1^{+/-}$mice before the onset of $A \beta$ deposition. In 3-month-old APPswe;PS1 $\triangle E 9 ; B A C E 1^{+/-}$mice compared with age-matched APPswe;PS1 $\triangle E 9$ mice, both APP- $\beta C T F$ and $\mathrm{A} \beta_{1-40} / \mathrm{A} \beta_{1-42}$ were significantly reduced $\left(\mathrm{A} \beta_{1-40}\right.$ reduced $31 \%, n=6, p<0.005$, Student's $t$ test; $\mathrm{A} \beta_{1-42}$ reduced $40 \%, n=$ $6, p<0.05$, Student's $t$ test) (Fig. $7 A, B$ ). To quantify the reduction in $\mathrm{A} \beta$ burden after the onset of $\mathrm{A} \beta$ deposition, we used 12and 20-month-old APPswe;PS1 $\triangle E 9 ; B A C E 1^{+/-}$mice. Filter trap (Xu et al., 2002) and unbiased stereological approaches were used to measure the amount of aggregated $A \beta$ and percentage of the brain occupied by $\mathrm{A} \beta$ deposits, respectively. Importantly, no A $\beta$ aggregation was detected from the filter trap assay in 12- or 20month old APPswe;PS1 $\triangle E 9$ transgenic mice in the BACE1 null background. The filter trap assay reveals a $27 \%$ reduction of $A \beta$ aggregates in brains of 12-month-old APPswe;PS1 $\triangle E 9$ transgenic mice compared with those in the $B A C E 1^{+/+}$background (Fig. $7 B)(n=5 ; t$ test, $p<0.05)$. However, no significant differences were observed in 20-month-old animals (filter trap blot not shown; quantification shown in Fig. $7 B$ ). Unbiased stereological analysis of brain sections of the same sets of mice revealed a $37 \%$ (Fig. $7 E)(n=5$; $t$ test, $p<0.01)$ decrease in percentages of brain volume occupied by $\mathrm{A} \beta$ plaques in 12-month-old APPswe; $P S 1 \triangle E 9 ; B A C E 1^{+/-}$(Fig. 7D) compared with APPswe;PS1 $1 E 9$; $B A C E 1^{+/+}$(Fig. 7C) mice. However, no significant reduction of A $\beta$ deposition was found in brains of 20 -month-old APPswe; $P S 1 \triangle E 9 ; B A C E 1^{+/-}$mice, paralleling the result from filter trap assays (Fig. 7E). Together, our results demonstrate that $\mathrm{A} \beta$ burden is sensitive to BACE1 dosage in young but not aged mice, indicating that $A \beta$ clearance mechanisms may be compromised in aged animals.

To determine whether $\mathrm{A} \beta$ deposits can be efficiently cleared from the brain by reducing the level of BACE1, we used an RNAi strategy to silence BACE1 in the hippocampus of aged (13- to 18 -month-old) APPswe;PS1 $\triangle E 9$ mice. First, we assessed the effectiveness of two shRNA ( $\mathrm{SH} 1$ and $\mathrm{SH} 2$ ) to silence BACE1 in $\mathrm{N} 2 \mathrm{~A}$ cells. Transient transfections of either $\mathrm{SH} 1$ or SH2 into N2A cells led to a significant reduction in levels of BACE1 mRNA and BACE1 protein, as well as secretion of $A \beta_{1-40}$ (supplemental Fig. S4, available at www.jneurosci.org as supplemental material). These data establish that both $\mathrm{SH} 1$ and $\mathrm{SH} 2$ are effective in knocking down BACE1 expression and its activity in cultured cells. We then stereotaxically injected LV expressing SH1 to silence $B A C E 1$ selectively in the hippocampus of APPswe;PS1 $\triangle E 9$ mice (Fig. $8 A$ ). We confirmed that the LV-SH1 infected neurons efficiently, as judged by GFP-positive cells with neuronal morphology in the dentate gyrus (Fig. $8 \mathrm{~B}$ ). One month after injec- 

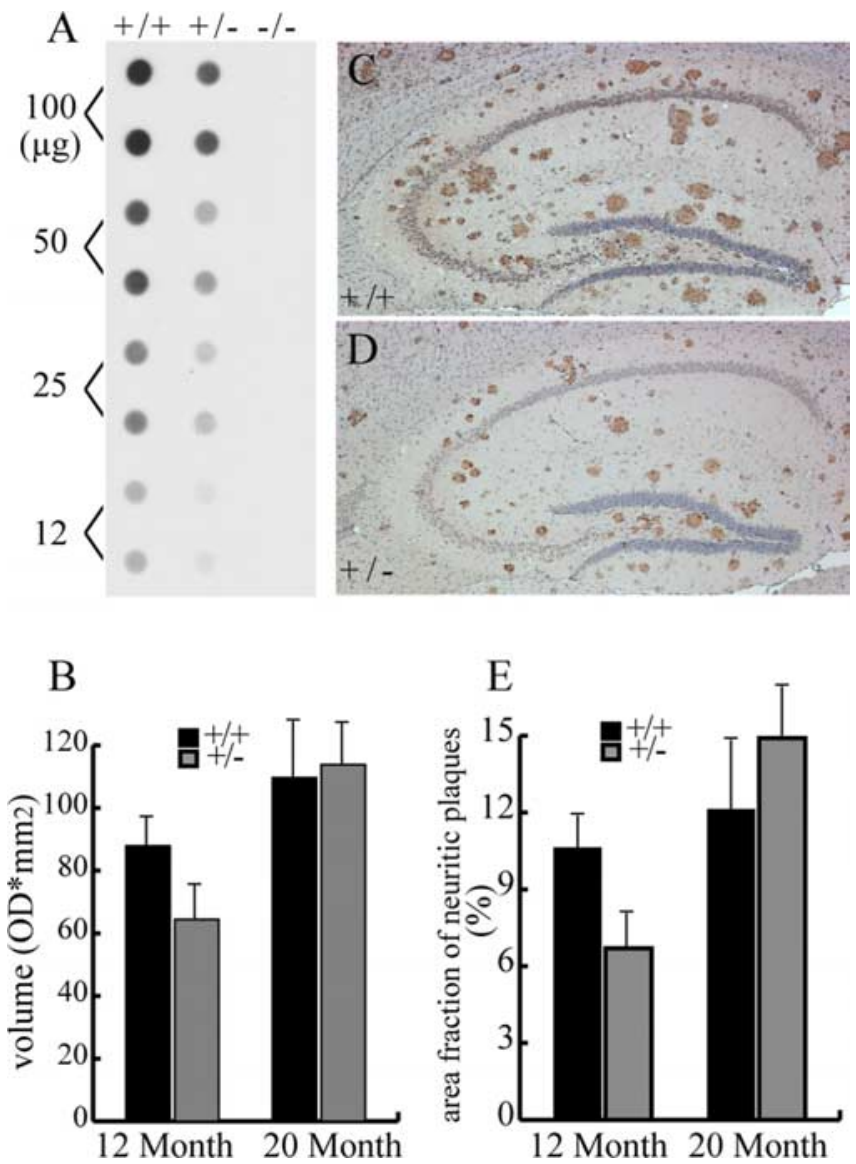

Figure 7. Reduced $A \beta$ burden in young, but not aged, $A P P$ swe;PS1 $\triangle E 9 B A C E 1^{+/-}$mice. $A$, Analysis of $A \beta$ aggregates using the filter trap assay from brains of 12-month-old APPswe; PS1 $1 E 9 ; B A C E 1^{-1-}$, APPSWe;PS1 $1 E 9 ; B A C E 1^{+/-}$, and APPswe;PS1 $1 E 9 ; B A C E 1^{+/+}$mice. As expected, no signals were detected in $A P P_{\text {swe; }} ; \mathrm{PS} 1 \triangle E 9 ; B A C E 1^{+/+}$mice. $\boldsymbol{B}$, Quantitative analysis of the levels of $A \beta$ aggregation in the brains of five pairs each of $A P P S w e ; P S 1 \triangle E 9$; $B A C E 1^{+/+}$and $A P P$ swe;PS1 $\triangle E 9 ; B A C E 1^{+/-}$mice at 12 and 20 months of age using the filter trap assay. OD, Optical density. C, D, Sagittal brain sections $(10 \mu \mathrm{m})$ from 12-month-old APPswe;PS1 $\triangle E 9 ; B A C E 1^{+/+}(C)$ and APPswe;PS1 $\triangle E 9 ; B A C E 1^{+/-}(D)$ immunostained with antibodies specific to ubiquitin. $E$, Unbiased stereological analysis of brain surface areas covered by neuritic plaques from 12-month-old $(n=7)$ and 20-month-old $(n=7)$ APPswe;PS1 $E$ E9; $B A C E 1^{+/+}$and APPSWe;PS1DE9;BACE1 ${ }^{+/-}$mice.

tion, we observed $\sim 38 \%$ reduction in $\mathrm{A} \beta$ burden (as assessed by unbiased stereological methods) in injected hippocampus compared with contralateral hippocampus (Fig. 8E,F,I,J,K). However, no differences were seen between cortices (Fig. $8 L$ ), and control injections had no effect on $\mathrm{A} \beta$ burden (Fig. $8 C, D, G, H, L$ ). Our findings demonstrate that $A \beta$ deposits can be efficiently cleared from the brain by silencing $B A C E 1$ and further validate BACE1 as a target for anti-amyloid therapy for AD.

\section{Discussion}

BACE1 is a major determinant of $\mathrm{A} \boldsymbol{\beta}$ amyloidosis in the CNS Previously, we proposed that the distributions and levels of BACE1 and BACE2/TACE, along with APP, are key determinants of susceptibility of the CNS to $\mathrm{A} \beta$ amyloidosis (Wong et al., 2001). We now provide multiple lines of evidence to support this hypothesis. First, BACE1 protein is abundant in the brain compared with other organs (Fig. $1 A$ ). Second, neurons are enriched in BACE1 (and APP); moreover, both of these proteins are conspicuous in presynaptic terminals in the hippocampus (Fig. 1D) (Sheng et al., 2003), findings that are consistent with reports documenting that APP is anterogradely transported to synapses
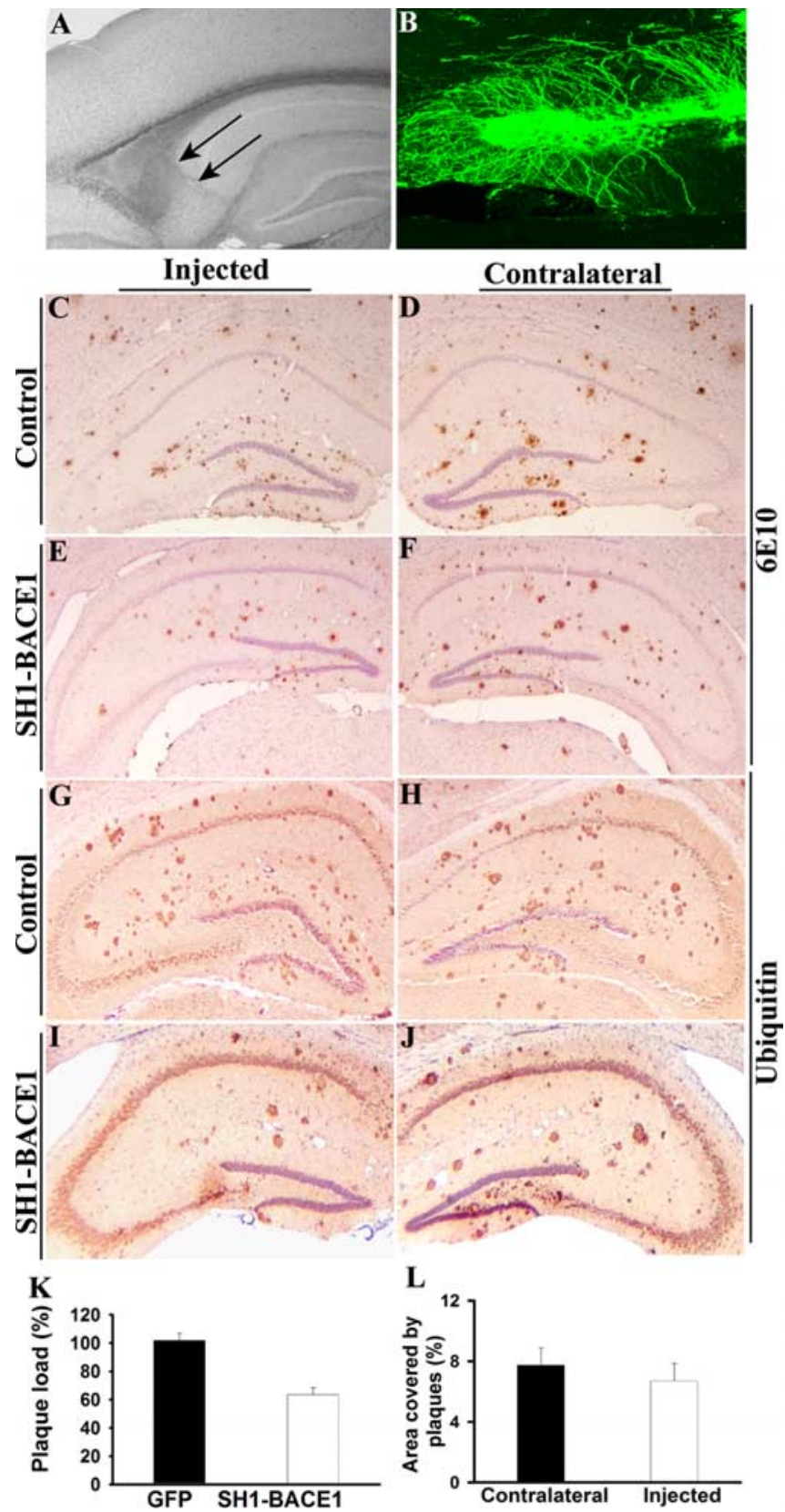

Figure 8. Silencing $B A C E 1$ through RNAi ameliorates $A \beta$ amyloidosis in the hippocampus of $A P P_{\text {swe }} / P S 1 \triangle E 9$ mice. $A$, A representative unstained bright-field image showing the needle track (arrows) after injection of LV. B, LV-SH1-BACE1, which coexpresses a reporter GFP, was stereotaxically injected into dentate gyrus of adult mouse hippocampus. Numerous cells in the dentate gyrus with neuronal morphology were GFP positive. $\boldsymbol{C}-\boldsymbol{F}$, Coronal hippocampal sections of 18-month-old APPswe/PS1 $\triangle E 9$ mice immunostained with monoclonal 6 E10 specific to $\mathrm{A} \beta$ and unilaterally injected with $\mathrm{LV}-\mathrm{GFP}(\boldsymbol{C}, \boldsymbol{D})$ or LV-SH1-BACE1 $(\boldsymbol{E}, \boldsymbol{F}) . \boldsymbol{C}$ and $\boldsymbol{E}$ are ipsilateral to injection sites, and $\boldsymbol{D}$ and $\boldsymbol{F}$ are contralateral to injection sites. $\mathbf{G}-\boldsymbol{J}$, Coronal hippocampal sections of 13- to 14-month-old APPswe/PS1 $\triangle E 9$ mice immunostained with antibody specific to ubiquitin and unilaterally injected with $\operatorname{LV}-\operatorname{GFP}(\boldsymbol{G}, \boldsymbol{H})$ or LV-SH1-BACE1 $(\boldsymbol{I}, \boldsymbol{J})$. $\boldsymbol{G}$ and $\boldsymbol{I}$ are ipsilateral to injection sites, and $\boldsymbol{H}$ and $\boldsymbol{J}$ are contralateral to injection sites. $\boldsymbol{K}$, Unbiased stereological analysis of ubiquitin-stained hippocampal sections of 13- to 18-month-old APPswe/ PS1 1 E9 mice. The percentage area covered by neuritic plaques in injected side was normalized to the contralateral side for each mouse. The black bar \pm SEM represents control injections $($ LV-GFP, $n=5)$, and the white bar \pm SEM represents LV-SH1-BACE1 $(n=5)$. Pairwise comparison using Student's $t$ test, $p<0.0006$. $L$, The percentage area covered by neuritic plaques was determined in the cortex above the hippocampus in the same sections as in $\boldsymbol{K}$. The black bar \pm SEM represents contralateral sides $(n=3)$, and the white bar \pm SEM is ipsilateral sides to LV-SH1-BACE1 injections $(n=3)$. Pairwise comparison using Student's $t$ test, $p=0.558$. 
in the CNS (Buxbaum et al., 1998; Lazarov et al., 2002; Sheng et al., 2002). Although initial reports indicated that BACE1 is anterogradely transported in CNS to a greater extent than in the PNS (Kamal et al., 2001; Sheng et al., 2003), recent studies failed to detect the transport of BACE1 in the PNS (Lazarov et al., 2005). Importantly, BACE1 and APP- $\beta C T F$ are present in terminal fields of some populations of neurons, and lesions of inputs to these regions reduce levels of APP, $\beta C T F s$, and $A \beta$ (Lazarov et al., 2002; Sheng et al., 2002). Third, physiologically high levels of BACE1 in neurons are coupled with low levels of $\alpha$-secretase and BACE2 activities, which is in contrast to the situation in non-neuronal cells in which levels of active BACE1 are very low and levels of BACE2 and/or $\alpha$-secretase activities are higher (Fig. 2).

\section{BACE1 plays critical roles in cognition and emotion}

Our demonstration that BACE1-deficient mice exhibit significant impairments in a number of hippocampus-dependent cognitive tasks provides direct evidence that BACE1 plays a critical role in learning and memory. Because a variety of possible substrates of BACE1 have been identified (Kitazume et al., 2001; Gruninger-Leitch et al., 2002; Lichtenthaler et al., 2003; Li and Sudhof, 2004), it is difficult to ascertain at this juncture which pathways may account for the cognitive deficits observed in $B A C E 1$ null mice. However, the observation that transgenic expression of $A P P$ swe and $P S 1 \triangle E 9$ is sufficient to restore the memory deficits occurring in $B A C E 1^{-/-}$mice suggests the APP processing pathway is a candidate for critical signaling mechanisms influencing cognitive functions. Consistent with this view is the finding that $A P P$-deficient mice appear to exhibit age-associated deficits in tasks that measure spatial reference memory (Dawson et al., 1999).

Although it is not known precisely how APP signaling impacts learning and memory, we postulate that a deficiency in neuronal AICD might contribute to the cognitive deficits observed in $B A C E 1$ null animals. The demonstration that a multimeric complex comprising AICD, Fe65, and Tip60 is capable of stimulating heterologous reporter constructs (Cao and Sudhof, 2001) coupled with the identification of a subset of nuclear factor $-\kappa \mathrm{B}$ genes regulated by the AICD-mediated transcription complex (Baek et al., 2002) are consistent with the view that AICD plays a signaling role analogous to that of NICD signaling. Recent studies indicate that AICD may play a role in neuronal differentiation through the c-Jun N-terminal kinase pathway (Kimberly et al., 2005). In this model, we suggest that the majority of AICD produced in neurons is BACE1 dependent and, because of the relative abundance of BACE1 enzymatic activities found in these cells (Fig. 2), we hypothesize that only a minor proportion is derived from nonamyloidogenic pathways, i.e., via BACE2 or $\alpha$-secretase activities. Thus, we envision that $B A C E 1^{-/-}$mice have low levels of AICD in neurons leading to misregulation of AICD/Fe65/Tip60dependent transcription, which results by as yet to be characterized processes leading to memory deficits observed in $B A C E 1^{-/-}$ mice. Consistent with this concept are observations that cognitive impairments are prevented in APPswe;PS1 $\triangle E 9 ; B A C E 1^{-1-}$ mice because the levels of AICD can be compensated by increases in levels of APP (albeit, in current experiments, mutant APP), by greater efficiency of $\epsilon$-cleavage mediated by PS1 $\Delta$ E9-dependent $\gamma$-secretase activity, or by both mechanisms. Although future investigations will be required to distinguish these possibilities, recent studies show that increased expression of APPswe is capable of preventing mild memory deficits in young $B A C E 1^{-1-}$ mice (Ohno et al., 2004). Thus, increased levels of APP appear to be sufficient to compensate for the postulated impaired signaling underlying cognitive deficits. Intriguingly, recent studies demonstrated that isoform-specific deletion of Fe65 is associated with memory deficits (Wang et al., 2004). One interpretation of this finding that supports our model is that interactions of AICD with Fe65-dependent pathways are important for normal cognitive function.

Although it is clear that the cognitive deficits observed in $B A C E 1$ null mice can be prevented in APPswe;PS1 $\triangle E 9$; $B A C E 1^{-/-}$mice, the emotional deficits occurring in our $B A C E 1$ null mice persisted in $A P P s w e ; P S 1 \triangle E 9 ; B A C E 1^{-/-}$mice. Consistent with this view are recent demonstrations that increases in motor activity found in BACE1 null mice as assessed by a Y-maze paradigm also occurred in APPswe;BACE $1^{-/-}$mice (Ohno et al., 2004). Moreover, isoform-specific Fe65 knock-out mice showed cognitive but not emotional deficits (Wang et al., 2004). Our findings strongly support the idea that other potential substrates of BACE1 (other than APP family members) may play critical roles in neuronal circuits that impact aspects of emotion in $B A C E 1^{-/-}$mice. These discoveries raise issues regarding mechanism-based alterations in physiology and behavior that may be associated with use of BACE1 inhibitors.

\section{BACE1 modulates synaptic function in hippocampus}

Although basal synaptic transmission is normal in $B A C E 1^{-/-}$ mice, we observed that there is an increase in PPF ratios. Changes in PPF have been correlated with probability of presynaptic release (Manabe et al., 1993), which would suggest a presynaptic role of BACE1 (which is present in terminals). However, recent data indicate that PPF can also arise from postsynaptic modifications, namely subunit composition of AMPA receptors (Rozov et al., 1998; Shin et al., 2005). Therefore, we cannot exclude a postsynaptic role for BACE1. Regardless of the exact role BACE1 plays in synaptic functions, the increase in PPF ratios indicates that a lack of BACE1 can increase synaptic transmission at higher frequencies. This observation may explain the larger dedepression in $B A C E 1^{-/-}$mice compared with control mice. However, contrary to our expectations, we did not observe any increase in LTP in $B A C E 1^{-/-}$mice, which is induced by the same TBS protocol. One possibility is that the expression of LTP and de-depression use different molecular mechanisms (Abeliovich et al., 1993; Lee et al., 2000). In this case, BACE1-dependent pathways may act as a negative regulator of de-depression mechanisms, while leaving LTP mechanisms intact. Our data showing an enhanced summation of responses in $B A C E 1^{-/-}$only during de-depression (Fig. $5 E$ ) indicates that the BACE1 probably act selectively on the induction mechanisms of de-depression. Regardless of the mechanism, the enhanced transmission of information at high frequencies (attributable to increase in ratio of PPF) suggests that altered BACE1 functions lead to interference with information transmission across synapses. Additionally, the enhanced de-depression (LTD reversal) observed in $B A C E 1^{-/-}$ mice may prevent stable expression of LTD and hence would interfere with information storage/memory. We speculate that the enhanced PPF and/or de-depression may be responsible for the behavioral deficits seen in our BACE1 null mice by either preventing effective transmission and/or storage of relevant information. In future studies, it will be interesting to clarify whether abnormalities in synaptic plasticity reported here in $B A C E 1^{-/-}$mice are dependent on APP processing. Crosses of $A P P$ transgenic mice to $B A C E 1^{-/-}$mice should be of value in clarifying this issue. Because we have shown that BACE1 also accumulates in CA3 in the hippocampus, it will be important to 
define whether deficits in synaptic transmission and plasticity also occur in this area in $B A C E 1^{-/-}$mice.

\section{Deletion of $B A C E 1$ prevents neuropathological abnormalities and age-associated cognitive deficits occurring in a mouse model of $A \boldsymbol{\beta}$ amyloidosis}

Because previous studies demonstrated that BACE1 is the $\beta$-secretase required for the secretion of $\mathrm{A} \beta$ peptides in the CNS (Fig. 2) (Cai et al., 2001; Luo et al., 2001; Roberds et al., 2001), it was anticipated that the ablation of BACE1 would impact the deposition of $A \beta$ in mouse models of amyloidosis. Indeed, this prediction is confirmed in this investigation documenting that the deletion of BACE1 completely prevented $\mathrm{A} \beta$ deposits in brains of aged APPswe;PS1 $\triangle E 9$ mice (supplemental Fig. S4, available at www.jneurosci.org as supplemental material). This outcome parallels observations showing the absence of $A \beta$ deposits in younger (12 month) APPswe mice lacking BACE1 (Luo et al., 2003). Moreover, we demonstrate that the levels of $\mathrm{p} 3$ fragments observed in vitro in BACE1 null cells (Cai et al., 2001) do not seem to contribute to development of $\mathrm{A} \beta$ deposition in vivo. These results are consistent with the view that no compensatory mechanisms exist for BACE1-driven $\mathrm{A} \beta$ production and indicate that BACE1 might be an excellent therapeutic target for reducing $\mathrm{A} \beta$ amyloidosis in AD (Citron, 2002; Luo et al., 2003).

Significantly, our finding that ablation of $B A C E 1$ prevented memory deficits in aged APPswe;PS1 $\triangle E 9$ mice provides strong support for the view that $A \beta$ peptides play important roles in age-associated cognitive impairments occurring in APPswe; $P S 1 \triangle E 9$ mice. Recent studies showed that deficits in a Y-maze alternation task in young APPswe mice (at a time before $\mathrm{A} \beta$ deposits were observed) can be prevented in the absence of BACE1 (Ohno et al., 2004), consistent with the hypothesis that oligomeric A $\beta$ (McLean et al., 1999; Walsh et al., 2002), also referred to as A $\beta$-derived diffusible ligands (Lambert et al., 1998; Holtzman et al., 2000; Klein et al., 2001; Gong et al., 2003), may be important contributors to the cognitive deficits occurring in these mouse models. Together, our results demonstrating that the ablation of BACE1 prevents the neuropathological abnormalities and age-associated cognitive deficits occurring in a mouse model of amyloidosis favor the view that BACE1 inhibitors may prove beneficial in efforts to attenuate $\mathrm{A} \beta$ amyloidosis in $\mathrm{AD}$. However, caution is necessary because complete inhibition of BACE1 could lead to memory deficits as occurs in $B A C E 1^{-/-}$mice. Analysis of conditional BACE1 knock-out mouse models will be of value in clarifying this issue.

Because these behavioral analyses were performed with aged mutant APP;PS1 mice lacking BACE1 in a hybrid strain background (C57BL/6 J and 129Sv), it was conceivable that the genetic background was a confounding factor in our Morris water maze study. To address this issue, it was important to verify that baseline performance was intact or to exclude the possibility that strain background impacts significantly the effect of APP;PS1 transgenes. Comparative Morris water maze analysis of mutant APP;PS1 mice on congenic C57BL/6/J background showed a similar effect compared with mutant APP;PS1 mice on an F2 C57BL/ 6/J;129Sv background (supplemental Figs. S1, S2, available at www.jneurosci.org as supplemental material). Moreover, one of the well known behavioral characteristics of the 129Sv strain that may affect the performance in the Morris Water maze is a relatively high floating time (Wolfer et al., 1997). Therefore, we compared time mice spent floating in our cohorts of F2 C57BL/6/ 129sv mice and observed no significant differences between the various genotypes used in our study (supplemental Fig. S2, available at www.jneurosci.org as supplemental material). Together, we conclude that the genetic background used in our studies did not affect the sensitivity of the Morris water maze task.

\section{$\mathrm{A} \beta$ burden is sensitive to the dosage of $B A C E 1$}

Because complete inhibition of BACE1 might be associated with mechanism-based toxicities, it may be important to modulate the extent of BACE1 inhibition to minimize potential toxicities. We show that $50 \%$ decrease in BACE1 levels significantly ameliorates $\mathrm{A} \beta$ deposition in young APPswe;PS1 $\triangle E 9 ; B A C E 1^{+/-}$mice (Fig. 7 ), establishing that $\mathrm{A} \beta$ burden is sensitive to $B A C E 1$ dosage. However, in aged APPswe;PS1 $\triangle E 9 ; B A C E 1^{+/-}$mice, the same decrease in BACE1 levels failed to alter $A \beta$ burden, suggesting that BACE1 is no longer a limiting factor in this aged mouse model, possibly attributable to compromised $\mathrm{A} \beta$ clearance mechanisms, including those mediated by apolipoprotein E (ApoE), ApoJ (clustrin), insulin degrading enzyme, and neprilysin (Iwata et al., 2001; Leissring et al., 2003; Marr et al., 2003; DeMattos, 2004; Iwata et al., 2004). Future studies will be necessary to clarify the ways by which $\mathrm{A} \beta$ clearance mechanisms may be compromised with age. Importantly, our demonstration that silencing $B A C E 1$ through RNAi ameliorates $\mathrm{A} \beta$ amyloidosis in aged mutant $A P P$; PS1 mice strongly support the view that $\mathrm{A} \beta$ deposits can be efficiently cleared by inhibiting BACE1 activity and further validates BACE1 as an excellent therapeutic target for anti-amyloid therapy in AD. During the course of this work, Singer et al. (2005) reported similar findings. Furthermore, they showed that silencing BACE1 through RNAi in the hippocampus attenuated cognitive deficits occurring in mutant APP mice (Singer et al., 2005). Together, our findings emphasize the potential values for development of compounds to inhibit BACE1 as well as drugs that regulate $A p o E$, clusterin, and $\mathrm{A} \beta$ degrading proteases in efforts to reduce $\mathrm{A} \beta$ burden.

In summary, although BACE1 is a high-priority therapeutic target, inhibition of BACE1 activity may not be completely free of mechanism-based consequences related to possible roles of BACE1-dependent APP/AICD signaling in cognitive functions. We anticipate that novel mechanism-based treatments such as BACE1 inhibitors will become available in the future. Therefore, it is critical to understand some of the BACE1/APP mechanisms that influence cognition and emotional circuits in the CNS. BACE1 conditional knock-out mouse models will be invaluable for clarifying whether cognitive deficits seen in $B A C E 1^{-1-}$ mice are related to development or to aging, and whether BACE1 is involved directly in memory formation, as well as for evaluating to what extent $\mathrm{A} \beta$ peptide-associated synaptic abnormalities are reversible after reductions of BACE1 activity. Finally, our studies here emphasize the pivotal roles that BACE1 plays in both health and disease, findings that are pertinent to the development of effective and safe anti-amyloid therapies for the treatment of this devastating disease of the elderly.

\section{References}

Abeliovich A, Chen C, Goda Y, Silva AJ, Stevens CF, Tonegawa S (1993) Modified hippocampal long-term potentiation in PKC gamma-mutant mice. Cell 75:1253-1262.

Allinson TM, Parkin ET, Turner AJ, Hooper NM (2003) ADAMs family members as amyloid precursor protein alpha-secretases. J Neurosci Res 74:342-352.

Andreasson KI, Savonenko A, Vidensky S, Goellner JJ, Zhang Y, Shaffer A, Kaufmann WE, Worley PF, Isakson P, Markowska AL (2001) Age- 
dependent cognitive deficits and neuronal apoptosis in cyclooxygenase-2 transgenic mice. J Neurosci 21:8198-8209.

Arendash GW, King DL, Gordon MN, Morgan D, Hatcher JM, Hope CE, Diamond DM (2001) Progressive, age-related behavioral impairments in transgenic mice carrying both mutant amyloid precursor protein and presenilin-1 transgenes. Brain Res 891:42-53.

Ashe KH (2001) Learning and memory in transgenic mice modeling Alzheimer's disease. Learn Mem 8:301-308.

Baek SH, Ohgi KA, Rose DW, Koo EH, Glass CK, Rosenfeld MG (2002) Exchange of N-CoR corepressor and Tip60 coactivator complexes links gene expression by NF-kappaB and beta-amyloid precursor protein. Cell 110:55-67.

Bennett BD, Babu-Khan S, Loeloff R, Louis JC, Curran E, Citron M, Vassar R (2000) Expression analysis of BACE2 in brain and peripheral tissues. J Biol Chem 275:20647-20651.

Bodendorf U, Danner S, Fischer F, Stefani M, Sturchler-Pierrat C, Wiederhold KH, Staufenbiel M, Paganetti P (2002) Expression of human betasecretase in the mouse brain increases the steady-state level of betaamyloid. J Neurochem 80:799-806.

Borchelt DR, Thinakaran G, Eckman CB, Lee MK, Davenport F, Ratovitsky T, Prada CM, Kim G, Seekins S, Yager D, Slunt HH, Wang R, Seeger M, Levey AI, Gandy SE, Copeland NG, Jenkins NA, Price DL, Younkin SG, Sisodia SS (1996) Familial Alzheimer's disease-linked presenilin 1 variants elevate Abeta1-42/1-40 ratio in vitro and in vivo. Neuron 17:1005-1013.

Buxbaum JD, Thinakaran G, Koliatsos V, O'Callahan J, Slunt HH, Price DL, Sisodia SS (1998) Alzheimer amyloid protein precursor in the rat hippocampus: transport and processing through the perforant path. J Neurosci 18:9629-9637.

Cai H, Wang Y, McCarthy D, Wen H, Borchelt DR, Price DL, Wong PC (2001) BACE1 is the major beta-secretase for generation of Abeta peptides by neurons. Nat Neurosci 4:233-234.

Cao X, Sudhof TC (2001) A transcriptionally [correction of transcriptively] active complex of APP with Fe65 and histone acetyltransferase Tip60. Science [Erratum (2001) 293:1436] 293:115-120.

Cao X, Sudhof TC (2004) Dissection of amyloid-beta precursor proteindependent transcriptional transactivation. J Biol Chem 279:24601-24611.

Citron M (2002) Beta-secretase as a target for the treatment of Alzheimer's disease. J Neurosci Res 70:373-379.

Crawley JN (1999) Behavioral phenotyping of transgenic and knockout mice: experimental design and evaluation of general health, sensory functions, motor abilities, and specific behavioral tests. Brain Res $835: 18-26$

Dawson GR, Seabrook GR, Zheng H, Smith DW, Graham S, O'Dowd G, Bowery BJ, Boyce S, Trumbauer ME, Chen HY, Van der Ploeg LH, Sirinathsinghji DJ (1999) Age-related cognitive deficits, impaired longterm potentiation and reduction in synaptic marker density in mice lacking the beta-amyloid precursor protein. Neuroscience 90:1-13.

De Strooper B (2003) Aph-1, Pen-2, and Nicastrin with Presenilin generate an active gamma-Secretase complex. Neuron 38:9-12.

DeMattos RB (2004) Apolipoprotein E dose-dependent modulation of beta-amyloid deposition in a transgenic mouse model of Alzheimer's disease. J Mol Neurosci 23:255-262.

Dudchenko PA (2004) An overview of the tasks used to test working memory in rodents. Neurosci Biobehav Rev 28:699-709.

Dykxhoorn DM, Novina CD, Sharp PA (2003) Killing the messenger: short RNAs that silence gene expression. Nat Rev Mol Cell Biol 4:457-467.

Eichenbaum H, Stewart C, Morris RG (1990) Hippocampal representation in place learning. J Neurosci 10:3531-3542.

Elbashir SM, Harborth J, Weber K, Tuschl T (2002) Analysis of gene function in somatic mammalian cells using small interfering RNAs. Methods 26:199-213.

Farzan M, Schnitzler CE, Vasilieva N, Leung D, Choe H (2000) BACE2, a beta-secretase homolog, cleaves at the beta site and within the amyloidbeta region of the amyloid-beta precursor protein. Proc Natl Acad Sci USA 97:9712-9717.

Francis R, McGrath G, Zhang J, Ruddy DA, Sym M, Apfeld J, Nicoll M, Maxwell M, Hai B, Ellis MC, Parks AL, Xu W, Li J, Gurney M, Myers RL, Himes CS, Hiebsch R, Ruble C, Nye JS, Curtis D (2002) aph-1 and pen- 2 are required for Notch pathway signaling, gamma-secretase cleavage of betaAPP, and presenilin protein accumulation. Dev Cell 3:85-97.
Gong Y, Chang L, Viola KL, Lacor PN, Lambert MP, Finch CE, Krafft GA, Klein WL (2003) Alzheimer's disease-affected brain: presence of oligomeric A beta ligands (ADDLs) suggests a molecular basis for reversible memory loss. Proc Natl Acad Sci USA 100:10417-10422.

Gruninger-Leitch F, Schlatter D, Kung E, Nelbock P, Dobeli H (2002) Substrate and inhibitor profile of BACE (beta-secretase) and comparison with other mammalian aspartic proteases. J Biol Chem 277:4687-4693.

Holsinger RM, McLean CA, Beyreuther K, Masters CL, Evin G (2002) Increased expression of the amyloid precursor beta-secretase in Alzheimer's disease. Ann Neurol 51:783-786.

Holtzman DM, Fagan AM, Mackey B, Tenkova T, Sartorius L, Paul SM, Bales K, Ashe KH, Irizarry MC, Hyman BT (2000) Apolipoprotein E facilitates neuritic and cerebrovascular plaque formation in an Alzheimer's disease model. Ann Neurol 47:739-747.

Hussain I, Powell D, Howlett DR, Tew DG, Meek TD, Chapman C, Gloger IS, Murphy KE, Southan CD, Ryan DM, Smith TS, Simmons DL, Walsh FS, Dingwall C, Christie G (1999) Identification of a novel aspartic protease (Asp 2) as beta-secretase. Mol Cell Neurosci 14:419-427.

Iwata N, Tsubuki S, Takaki Y, Shirotani K, Lu B, Gerard NP, Gerard C, Hama E, Lee HJ, Saido TC (2001) Metabolic regulation of brain Abeta by neprilysin. Science 292:1550-1552.

Iwata N, Mizukami H, Shirotani K, Takaki Y, Muramatsu S, Lu B, Gerard NP, Gerard C, Ozawa K, Saido TC (2004) Presynaptic localization of neprilysin contributes to efficient clearance of amyloid- $\beta$ peptide in mouse brain. J Neurosci 24:991-998.

Jankowsky JL, Xu G, Fromholt D, Gonzales V, Borchelt DR (2003) Environmental enrichment exacerbates amyloid plaque formation in a transgenic mouse model of Alzheimer disease. J Neuropathol Exp Neurol 62:1220-1227.

Kamal A, Almenar-Queralt A, LeBlanc JF, Roberts EA, Goldstein LS (2001) Kinesin-mediated axonal transport of a membrane compartment containing beta-secretase and presenilin-1 requires APP. Nature 414:643648.

Kamenetz F, Tomita T, Hsieh H, Seabrook G, Borchelt D, Iwatsubo T, Sisodia S, Malinow R (2003) APP processing and synaptic function. Neuron 37:925-937.

Kimberly WT, Zheng JB, Town T, Flavell RA, Selkoe DJ (2005) Physiological regulation of the $\beta$-amyloid precursor protein signaling domain by c-Jun N-terminal kinase JNK3 during neuronal differentiation. J Neurosci 25:5533-5543.

King JA, Burgess N, Hartley T, Vargha-Khadem F, O’Keefe J (2002) Human hippocampus and viewpoint dependence in spatial memory. Hippocampus 12:811-820.

Kitazume S, Tachida Y, Oka R, Shirotani K, Saido TC, Hashimoto Y (2001) Alzheimer's beta-secretase, beta-site amyloid precursor protein-cleaving enzyme, is responsible for cleavage secretion of a Golgi-resident sialyltransferase. Proc Natl Acad Sci USA 98:13554-13559.

Klein WL, Krafft GA, Finch CE (2001) Targeting small Abeta oligomers: the solution to an Alzheimer's disease conundrum? Trends Neurosci 24:219-224.

Lambert MP, Barlow AK, Chromy BA, Edwards C, Freed R, Liosatos M, Morgan TE, Rozovsky I, Trommer B, Viola KL, Wals P, Zhang C, Finch CE, Krafft GA, Klein WL (1998) Diffusible, nonfibrillar ligands derived from Abeta1-42 are potent central nervous system neurotoxins. Proc Natl Acad Sci USA 95:6448-6453.

Lazarov O, Lee M, Peterson DA, Sisodia SS (2002) Evidence that synaptically released $\beta$-amyloid accumulates as extracellular deposits in the hippocampus of transgenic mice. J Neurosci 22:9785-9793.

Lazarov O, Morfini GA, Lee EB, Farah MH, Szodorai A, DeBoer SR, Koliatsos VE, Kins S, Lee VM, Wong PC, Price DL, Brady ST, Sisodia SS (2005) Axonal transport, amyloid precursor protein, kinesin-1, and the processing apparatus: revisited. J Neurosci 25:2386-2395.

Lee EB, Zhang B, Liu K, Greenbaum EA, Doms RW, Trojanowski JQ, Lee VM (2005) BACE overexpression alters the subcellular processing of APP and inhibits Abeta deposition in vivo. J Cell Biol 168:291-302.

Lee HK, Barbarosie M, Kameyama K, Bear MF, Huganir RL (2000) Regulation of distinct AMPA receptor phosphorylation sites during bidirectional synaptic plasticity. Nature 405:955-959.

Lee MK, Borchelt DR, Kim G, Thinakaran G, Slunt HH, Ratovitski T, Martin LJ, Kittur A, Gandy S, Levey AI, Jenkins N, Copeland N, Price DL, Sisodia 
SS (1997) Hyperaccumulation of FAD-linked presenilin 1 variants in vivo. Nat Med 3:756-760.

Leissring MA, Farris W, Chang AY, Walsh DM, Wu X, Sun X, Frosch MP, Selkoe DJ (2003) Enhanced proteolysis of beta-amyloid in APP transgenic mice prevents plaque formation, secondary pathology, and premature death. Neuron 40:1087-1093.

Li Q, Sudhof TC (2004) Cleavage of amyloid-beta precursor protein and amyloid-beta precursor-like protein by BACE 1. J Biol Chem 279:10542-10550.

Lichtenthaler SF, Dominguez DI, Westmeyer GG, Reiss K, Haass C, Saftig P, De Strooper B, Seed B (2003) The cell adhesion protein P-selectin glycoprotein ligand-1 is a substrate for the aspartyl protease BACE1. J Biol Chem 278:48713-48719.

Lin X, Koelsch G, Wu S, Downs D, Dashti A, Tang J (2000) Human aspartic protease memapsin 2 cleaves the beta-secretase site of beta-amyloid precursor protein. Proc Natl Acad Sci USA 97:1456-1460.

Luo Y, Bolon B, Kahn S, Bennett BD, Babu-Khan S, Denis P, Fan W, Kha H, Zhang J, Gong Y, Martin L, Louis JC, Yan Q, Richards WG, Citron M, Vassar R (2001) Mice deficient in BACE1, the Alzheimer's betasecretase, have normal phenotype and abolished beta-amyloid generation. Nat Neurosci 4:231-232.

Luo Y, Bolon B, Damore MA, Fitzpatrick D, Liu H, Zhang J, Yan Q, Vassar R, Citron M (2003) BACE1 (beta-secretase) knockout mice do not acquire compensatory gene expression changes or develop neural lesions over time. Neurobiol Dis 14:81-88.

Manabe T, Wyllie DJ, Perkel DJ, Nicoll RA (1993) Modulation of synaptic transmission and long-term potentiation: effects on paired pulse facilitation and EPSC variance in the CA1 region of the hippocampus. J Neurophysiol 70:1451-1459.

Markowska AL, Long JM, Johnson CT, Olton DS (1993) Variable-interval probe test as a tool for repeated measurements of spatial memory in the water maze. Behav Neurosci 107:627-632.

Marr RA, Rockenstein E, Mukherjee A, Kindy MS, Hersh LB, Gage FH, Verma IM, Masliah E (2003) Neprilysin gene transfer reduces human amyloid pathology in transgenic mice. J Neurosci 23:1992-1996.

Mayeux R (2003) Apolipoprotein E, Alzheimer disease, and African Americans. Arch Neurol 60:161-163.

McLean CA, Cherny RA, Fraser FW, Fuller SJ, Smith MJ, Beyreuther K, Bush AI, Masters CL (1999) Soluble pool of Abeta amyloid as a determinant of severity of neurodegeneration in Alzheimer's disease. Ann Neurol 46:860-866.

Morris JC, Price AL (2001) Pathologic correlates of nondemented aging, mild cognitive impairment, and early-stage Alzheimer's disease. J Mol Neurosci 17:101-118.

Morris R (1984) Developments of a water-maze procedure for studying spatial learning in the rat. J Neurosci Methods 11:47-60.

Naruse S, Thinakaran G, Luo JJ, Kusiak JW, Tomita T, Iwatsubo T, Qian X, Ginty DD, Price DL, Borchelt DR, Wong PC, Sisodia SS (1998) Effects of PS1 deficiency on membrane protein trafficking in neurons. Neuron 21:1213-1221.

Ohno M, Sametsky EA, Younkin LH, Oakley H, Younkin SG, Citron M, Vassar R, Disterhoft JF (2004) BACE1 deficiency rescues memory deficits and cholinergic dysfunction in a mouse model of Alzheimer's disease. Neuron 41:27-33.

Paddison PJ, Hannon GJ (2002) RNA interference: the new somatic cell genetics? Cancer Cell 2:17-23.

Petersen RC (2003) Mild cognitive impairment clinical trials. Nat Rev Drug Discov 2:646-653.

Price DL, Sisodia SS (1998) Mutant genes in familial Alzheimer's disease and transgenic models. Annu Rev Neurosci 21:479-505.

Prut L, Belzung C (2003) The open field as a paradigm to measure the effects of drugs on anxiety-like behaviors: a review. Eur J Pharmacol 463:3-33.

Roberds SL, Anderson J, Basi G, Bienkowski MJ, Branstetter DG, Chen KS, Freedman SB, Frigon NL, Games D, Hu K, Johnson-Wood K, Kappenman KE, Kawabe TT, Kola I, Kuehn R, Lee M, Liu W, Motter R, Nichols NF, Power M, et al. (2001) BACE knockout mice are healthy despite lacking the primary beta-secretase activity in brain: implications for Alzheimer's disease therapeutics. Hum Mol Genet 10:1317-1324.

Rockenstein E, Mante M, Alford M, Adame A, Crews L, Hashimoto M, Esposito L, Mucke L, Masliah E (2005) High beta-secretase activity elicits neurodegeneration in transgenic mice despite reductions in amyloid-beta levels: implications for the treatment of Alzheimer disease. J Biol Chem 280:32957-32967.

Rozov A, Zilberter Y, Wollmuth LP, Burnashev N (1998) Facilitation of currents through rat $\mathrm{Ca}^{2+}$-permeable AMPA receptor channels by activity-dependent relief from polyamine block. J Physiol (Lond) 511:361-377.

Rubinson DA, Dillon CP, Kwiatkowski AV, Sievers C, Yang L, Kopinja J, Rooney DL, Ihrig MM, McManus MT, Gertler FB, Scott ML, Van Parijs L (2003) A lentivirus-based system to functionally silence genes in primary mammalian cells, stem cells and transgenic mice by RNA interference. Nat Genet 33:401-406.

Sabo SL, Ikin AF, Buxbaum JD, Greengard P (2003) The amyloid precursor protein and its regulatory protein, FE65, in growth cones and synapses in vitro and in vivo. J Neurosci 23:5407-5415.

Saura CA, Choi SY, Beglopoulos V, Malkani S, Zhang D, Shankaranarayana Rao BS, Chattarji S, Kelleher III RJ, Kandel ER, Duff K, Kirkwood A, Shen J (2004) Loss of presenilin function causes impairments of memory and synaptic plasticity followed by age-dependent neurodegeneration. Neuron 42:23-36.

Savonenko A, Xu GM, Melnikova T, Morton JL, Gonzales V, Wong MP, Price DL, Tang F, Markowska AL, Borchelt DR (2005) Episodic-like memory deficits in the APPswe/PS1dE9 mouse model of Alzheimer's disease: relationships to beta-amyloid deposition and neurotransmitter abnormalities. Neurobiol Dis 18:602-617.

Selkoe D, Kopan R (2003) Notch and Presenilin: regulated intramembrane proteolysis links development and degeneration. Annu Rev Neurosci 26:565-597.

Sheng JG, Price DL, Koliatsos VE (2002) Disruption of corticocortical connections ameliorates amyloid burden in terminal fields in a transgenic model of A $\beta$ amyloidosis. J Neurosci 22:9794-9799.

Sheng JG, Price DL, Koliatsos VE (2003) The beta-amyloid-related proteins presenilin 1 and BACE1 are axonally transported to nerve terminals in the brain. Exp Neurol 184:1053-1057.

Shin J, Shen F, Huguenard JR (2005) Polyamines modulate AMPA receptor dependent synaptic responses in immature layer $\mathrm{V}$ pyramidal neurons. J Neurophysiol 93:2634-2643.

Singer O, Marr RA, Rockenstein E, Crews L, Coufal NG, Gage FH, Verma IM, Masliah E (2005) Targeting BACE1 with siRNAs ameliorates Alzheimer disease neuropathology in a transgenic model. Nat Neurosci 8: $1343-1349$.

Sinha S, Anderson JP, Barbour R, Basi GS, Caccavello R, Davis D, Doan M, Dovey HF, Frigon N, Hong J, Jacobson-Croak K, Jewett N, Keim P, Knops J, Lieberburg I, Power M, Tan H, Tatsuno G, Tung J, Schenk D, et al. (1999) Purification and cloning of amyloid precursor protein betasecretase from human brain. Nature 402:537-540.

Takasugi N, Tomita T, Hayashi I, Tsuruoka M, Niimura M, Takahashi Y, Thinakaran G, Iwatsubo T (2003) The role of presenilin cofactors in the gamma-secretase complex. Nature 422:438-441.

Vassar R (2002) Beta-secretase (BACE) as a drug target for Alzheimer's disease. Adv Drug Deliv Rev 54:1589-1602.

Vassar R, Bennett BD, Babu-Khan S, Kahn S, Mendiaz EA, Denis P, Teplow DB, Ross S, Amarante P, Loeloff R, Luo Y, Fisher S, Fuller J, Edenson S, Lile J, Jarosinski MA, Biere AL, Curran E, Burgess T, Louis JC, et al. (1999) Beta-secretase cleavage of Alzheimer's amyloid precursor protein by the transmembrane aspartic protease BACE. Science 286:735-741.

Walsh DM, Klyubin I, Fadeeva JV, Cullen WK, Anwyl R, Wolfe MS, Rowan MJ, Selkoe DJ (2002) Naturally secreted oligomers of amyloid beta protein potently inhibit hippocampal long-term potentiation in vivo. Nature 416:535-539.

Wang B, Hu Q, Hearn MG, Shimizu K, Ware CB, Liggitt DH, Jin LW, Cool BH, Storm DR, Martin GM (2004) Isoform-specific knockout of FE65 leads to impaired learning and memory. J Neurosci Res 75:12-24.

Winocur G, Hasher L (2004) Age and time-of-day effects on learning and memory in a non-matching-to-sample test. Neurobiol Aging 25:1107-1115.

Wolfer DP, Muller U, Stogliar M, Lipp HP (1997) Assessing the effects of the $129 / \mathrm{Sv}$ genetic background on swimming navigation learning in transgenic mutants: a study using mice with a modified $\beta$-amyloid precursor protein gene. Brain Res 771:1-13.

Wong HK, Sakurai T, Oyama F, Kaneko K, Wada K, Miyazaki H, Kurosawa 
M, De Strooper B, Saftig P, Nukina N (2005) $\beta$-Subunits of voltage-gated sodium channels are novel substrates of $\beta$-site amyloid precursor proteincleaving enzyme (BACE1) and $\gamma$-secretase. J Biol Chem 280:23009-23017.

Wong PC, Price DL, Cai H (2001) The brain's susceptibility to amyloid plaques. Science 293:1434.

Wong PC, Cai H, Borchelt DR, Price DL (2002) Genetically engineered mouse models of neurodegenerative diseases. Nat Neurosci 5:633-639.

Xu G, Gonzales V, Borchelt DR (2002) Rapid detection of protein aggregates in the brains of Alzheimer patients and transgenic mouse models of amyloidosis. Alzheimer Dis Assoc Disord 16:191-195.

Yamamoto T, Hirano A (1986) A comparative study of modified Bielschowsky, Bodian and thioflavin S stains on Alzheimer's neurofibrillary tangles. Neuropathol Appl Neurobiol 12:3-9.

Yan R, Bienkowski MJ, Shuck ME, Miao H, Tory MC, Pauley AM, Brashier JR, Stratman NC, Mathews WR, Buhl AE, Carter DB, Tomasselli AG, Parodi LA, Heinrikson RL, Gurney ME (1999) Membrane-anchored as- partyl protease with Alzheimer's disease beta-secretase activity. Nature 402:533-537.

Yan R, Munzner JB, Shuck ME, Bienkowski MJ (2001) BACE2 functions as an alternative alpha-secretase in cells. J Biol Chem 276:34019-34027.

Yang LB, Lindholm K, Yan R, Citron M, Xia W, Yang XL, Beach T, Sue L, Wong P, Price D, Li R, Shen Y (2003) Elevated beta-secretase expression and enzymatic activity detected in sporadic Alzheimer disease. Nat Med 9:3-4.

Zhao Q, Lee FS (2003) The transcriptional activity of the APP intracellular domain-Fe65 complex is inhibited by activation of the NF-kappaB pathway. Biochemistry 42:3627-3634.

Zheng H, Jiang M, Trumbauer ME, Sirinathsinghji DJ, Hopkins R, Smith DW, Heavens RP, Dawson GR, Boyce S, Conner MW, Stevens KA, Slunt HH, Sisodia SS, Chen HY, Van der Ploeg LH (1995) beta-Amyloid precursor protein-deficient mice show reactive gliosis and decreased locomotor activity. Cell 81:525-531. 